\title{
Proto-Basin Types of North China Craton (NCC) in Late Triassic and Its Implication for Regional Tectonics of Initial Craton Destruction ${ }^{1}$
}

\author{
Yang Minghui ${ }^{2}$, Liu Chiyang ${ }^{3}$, Zeng Peng ${ }^{1}$, Bai Hua ${ }^{1}$ and Zhou $\mathrm{Jin}^{1}$ \\ ${ }^{1}$ College of Geosciences, China University of Petroleum, Beijing 102249; \\ ${ }^{2}$ State Key Laboratory of Petroleum Resource and Prospecting, \\ China University of Petroleum, Beijing, 102249; \\ ${ }^{3}$ State key Laboratory of Continental Dynamics, Northwest University, Xi'an, 710069
}

China

\section{Introduction}

As a long-term geological process with widespread influence, destruction of the North China Craton (NCC) displays many important geological phenomena and attracts interest of many domestic and overseas researchers engaged in geology, geochemistry and geophysics, etc. The NCC has its own attributes of occurrence and development. Its destruction may have connections with the activities of YYOB and QDOB respectively, distributed in the north and the south, as well as with the subduction between Indian plate and Pacific plate. Even though the inhomogeneity of the destruction process becomes prominent in terms of time, space and destruction intensity, significant disputes still exist on several specific problems. The peak period of NCC destruction was in late Jurassic-early Cretaceous. However, there are various opinions concerning the determination of beginning stage, e. g. 1) late Triassic (Menzies et al., 1998; Gao et al., 2002; Lu Fengxiang et al., 2000; Yang Jinhui et al., 2009); 2) late Mesozoic (Deng Jinfu et al.,1994; Wu Fuyuan et al., 1999; Zhai Mingguo et al., 2003; Lu Fengxiang et al.,2006); 3) Cenozoic (Menzies et al., 1993; Griffin et al., 1998; Xu, 2001) and Meso-Cenozoic (Xu Wenliang et al., 2000); or even in 4) late Paleozoic (Xu Yigang et al., 2009; Li Hongyan et al., 2009). The range of NCC destruction is in the east of the gravity gradient zone of (from Daxing'anling Mountains to) Taihangshan Mountains (Xu Yigang et al., 2006) , according to other opinions, or already had moved westward to nearby of Luliangshan Mountain (Ren Zhanli et al., 2005; Xiao Yuanyuan et al., 2007) around the Shanxi province as transitional or conversional area (Xing Zuoyun et al., 2006). The destruction intensity is getting gradually stronger from west to east, extremely severe in the east (Wei Wenbo et al., 2008), stable in the western Ordos area which remains as typical craton without disturbance in its deep layer by NCC destruction (Qiu Ruizhao et al., 2004; Jia Shixu et al., 2005). NCC destruction, as a geological process, was a kind of gradually

\footnotetext{
1 Supported by Key Program of National Natural Science Foundation of China (No: 90814005) and Marine Reservoir Evolution and hydrocarbon enrichment Laboratory Fund.
} 
varying chemical erosion (Xu, 2001; Fan et al., 2001; Zhang et al., 2002; Xu et al., 2003, 2004) or mutational physical delamination (Deng Jinfu et al., 1994, 2006) in deep layer which behaved as lithosphere thinning; however, it acted as drastic crustal deformation (contraction and/ or extension) (Yu Fusheng et al., 2002; Duan Qiuliang et al., 2007), or largescale magmatic activity (Guo et al., 2001; Zhang et al., 2002) and mineralization (Zhai Mingguo et al., 2002; Zhai et al., 2002; Liu Jianming et al., 2003). For the NCC event, there are deficiencies in analytical results about fillings and denudations of the sedimentary basin scale at the moment, although the incomplete or lacking of stratigraphic records can be "windows" of lithosphere evolution in geotectonic research(Liu Shaofeng et al., 1996, 2004; Davis et al., 2001; Yang Geng et al., 2001; Darby et al., 2001; Li Zhong et al., 2007). In recent years, basin research and comparison on NCC destruction become possible, due to 1) expanded knowledge to the deeper stratigraphic framework and structure of the basin obtained from seismic reflection profiles and drilling wells; 2) better restriction to the time series of stratigraphic records of the NCC area based on accurate isotopic dating data. Based on the integration of former data, this paper will focus on the area of comparison and analysis of the NCC basin filling, deposition and tectonic deformation in late Triassic and bring forward new understandings to the proto-basin type, tectonic deformation division and tectonic destruction process of the researching areas.

\section{Regional geological background}

NCC basin's evolution and its time-space distributing characteristics are closely linked to its regional structural geological background. Since Paleozoic, the tectonic development of China mainland is under the control of three global dynamics systems: paleo-Asian ocean, Tethys ocean and paleo-Pacific dynamics systems (Ren Jishun, 1994). Considering from plate tectonics view, NCC was jointly influenced by Siberian plate, Yangtze plate, west Pacific ocean plate and Indian plate, and collisions, extrusions and subductions among plates directly resulted in the formation of YYOB and QDOB in the north and the south of eastern China mainland (Fig. 1).

YYOB is a collision zone with certain width and numerous fragments of ancient continental crusts resulted from the collision and extrusion between NCC plate and Siberian plate ( $\mathrm{Li}$ Shuanglin, 1998; Yang Baojun et al., 2003). The patchwork of the north edge of NCC plate and the south edge of Siberian plate was formed in late Paleozoic, and the final suture zone locates in Xilinhot (Hegen Mountains)-Sonidyouqi-Suolunobo in north Inner Mongolia (Wang Quan et al., 1991), which marks the end of influence of the paleo-Asian ocean tectonic domain on basin tectonic evolution in north China, and YYOB has become a limited boundary of Cenozoic tectonic evolution in NCC basin. QDOB lies across the middle of China mainland, as a key to researches on China mainland. Researches result of orogen patterns, characteristics of lithosphere structure, high pressure and ultra-high pressure metamorphism, geodynamic mechanism and other aspects indicate that this orogen was formed in late Triassic due to interplate collision and orogeny caused by subduction of the north edge of Yangtze plate into the lower part of NCC during Yangtze plate's northward drift (Zhang Guowei et al, 2003).

Therefore, the relationship between the orogen formation and the basin evolution shows that the formation of QDOB (resulted from the collision and extrusion of Yangtze plate and NCC) in Indosinian makes the whole NCC in almost south-north extrusion. Because YYOB at the north edge of NCC is a fixed limited boundary, there are a large number of thrusting 
nappe structures and corresponding interplate foreland basins developed along the south and north edges of NCC. And there are also a great number of EW or NWW striking thrusting nappe structures at Yanshan orogen, southern North China basin and Bohai bay basin. The extrusion effects between Yangtze plate and NCC may be prolonged until the early Yanshan stage (Du Xudong et al, 1999).

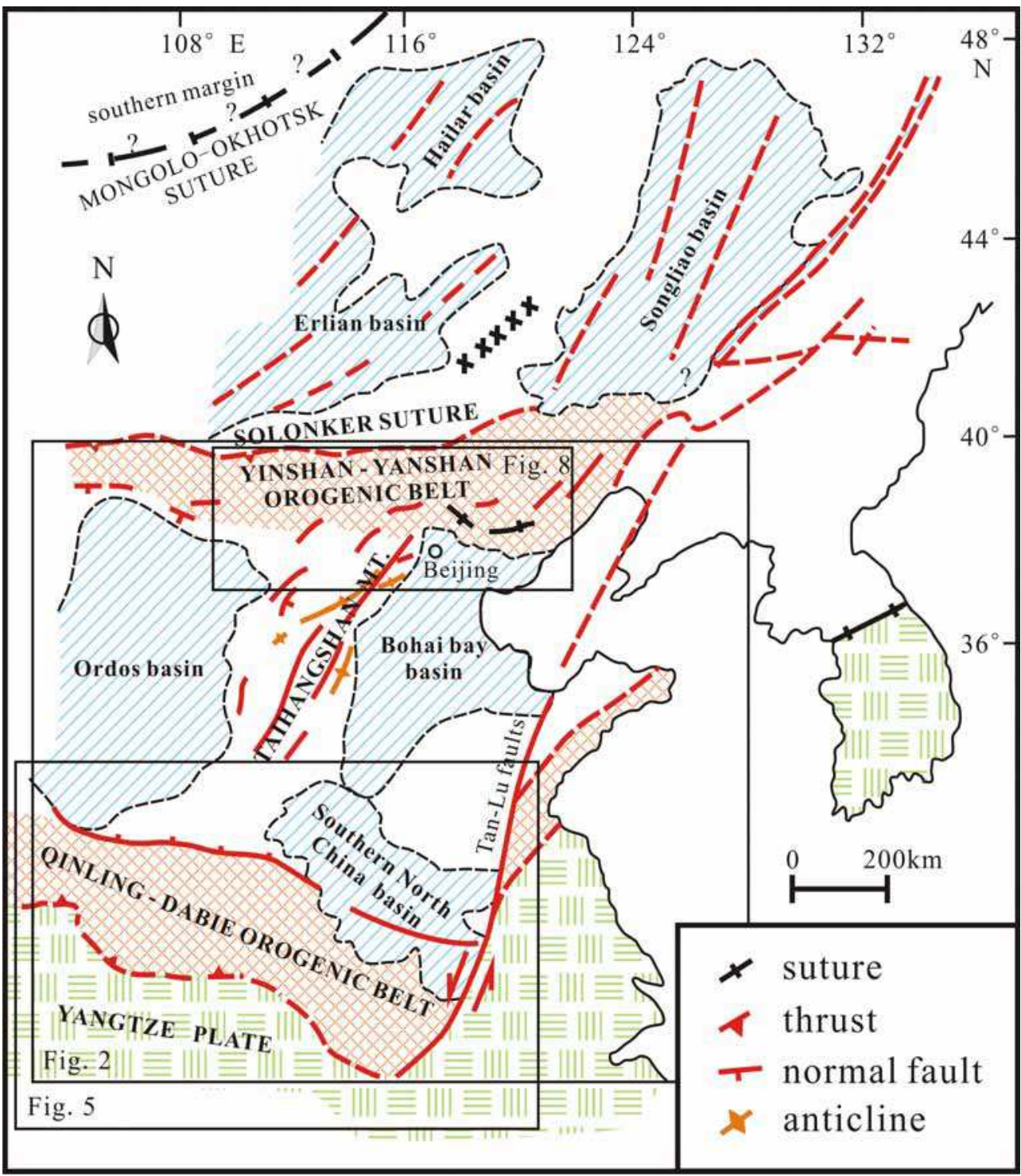

Fig. 1. Regional tectonic patterns of NCC and its adjacent area (simplified from Zheng Yadong et al., 2000). 


\section{Distribution of contemporaneous residual formations of NCC in late Triassic}

The residual formations of late Triassic in NCC was divided into multiple areas: First of all, the sufficiently developed formation of western Ordos in the middle zone and the sedimentary-subsidence center in southwest side, which extend eastward to the middle area of Shanxi province and western Henan province as whole-blocks; secondly, areas in the north zone scattering along western Liaoning-western Beijing-northern Hebei province; finally, areas in the south zone are developed in the north of Mt. Qingling along western Henan-southern Shanxi provinces (Fig. 2). Formations at the north and south edges have been all influenced by the late orogenic deformation, which were mostly developed as fragmentations due to the clamping of thrust fault.

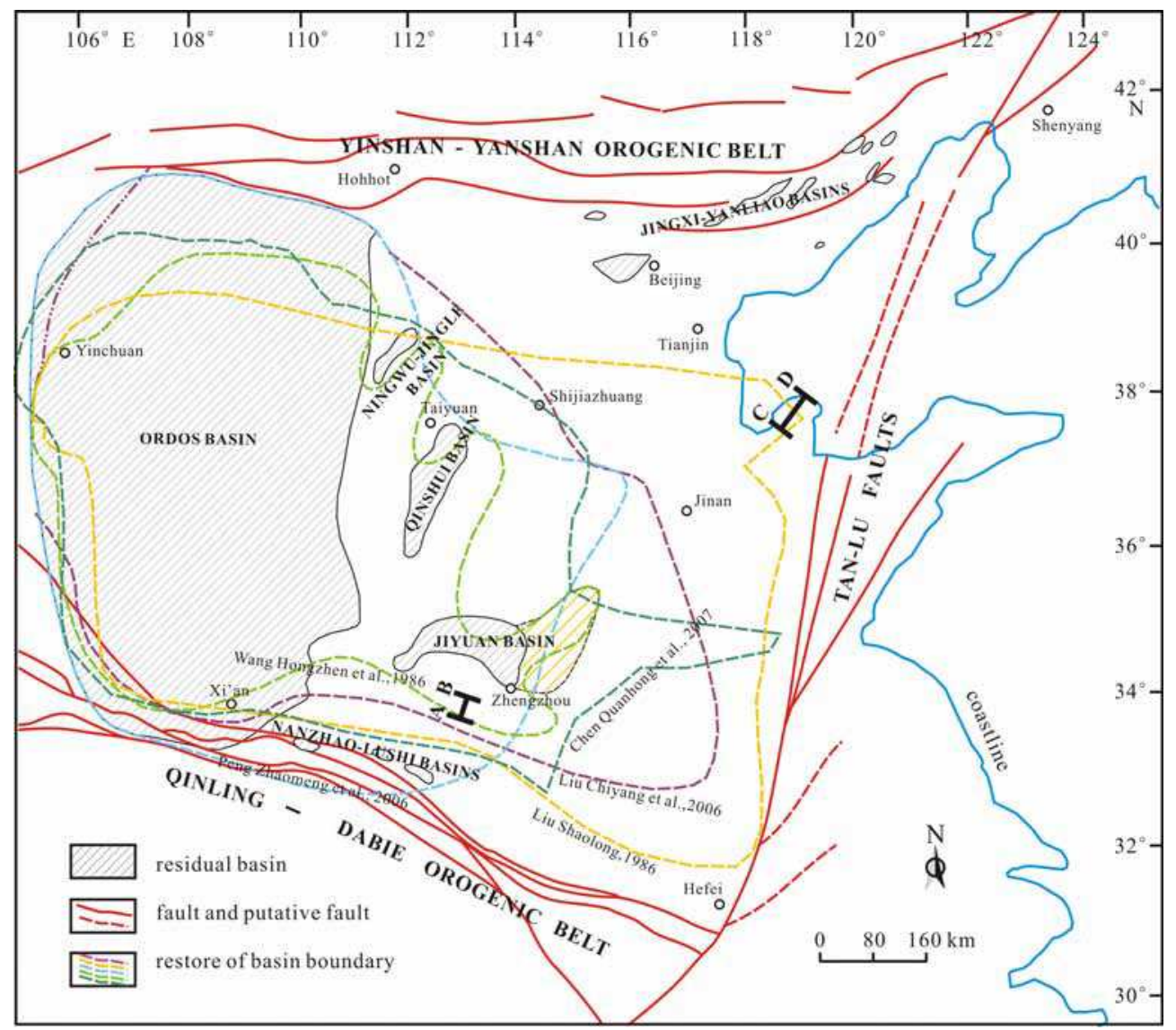

Fig. 2. Distribution map of residual formation of upper Triassic in NCC and its adjacent area. 


\subsection{Distribution of Late Triassic in Ordos-Middle Shanxi-Western Henan Regions}

Upper Triassic in Ordos basin is called Yanchang Formation in general terms (Fig. 3a), which intermittently extends eastward to Qinshui basin of middle Shanxi province (Fig. 3b) and Ningwu--Jingle basin, etc. The approximate thickness of Yanchang Formation is $1300 \mathrm{~m}$, which is a set of terrigenous clastic rocks mainly featured in fluvial and lacustrine deposits: the dominant sedimentary facies of lower part is fluvial and lacustrine with medium-coarse sandstone; the middle part with fluvial-delta-lacustrine; and the upper part with sandstone and mudstone, coals locally developed in the north of Shaanxi province (Fu Jinghua et al., 2005; Deng Xiuqin et al., 2008; Li Wenhou et al., 2009). In the horizontal, the main sedimentary type of Yanchang Formation is fluvial-delta sandstone with significant variations of lithology and lithofacies region. In the north of $\mathrm{N} 38^{\circ}$, the sediments are thinner in thickness and bigger in grain size (100-600 m); while the south part develop in the lacustrine environment with dark mudstone, and sediments are bigger in thickness(10001400 m) (Changqing Oilfield, 1992; Yang Minghui et al., 2007; Cao Hongxia et al., 2008). The southwest of Shigouyi-Pingliang-Huanxian region develops fan/fan-deltas with conglomerate or pebbled sandstone; the formation's maximum thickness in area along Shigouyi-Huating is greater than 2,500 m (Liu Shaofeng et al., 1997; Zhao Wenzhi et al., 2006; Zhao Hongge et al., 2007). The outcrops of Yanchang Formation in Ningwu-Jingle basin is about $600 \mathrm{~m}$ thick, and is comparatively well developed. The formation in this region develops thick/ super-thick layers of gray/green sandstones, and includes thin-layer mudstones or siltstones occasionally. There are parallel unconformities between the formations and purplish-red middle Triassic Ermaying Formation and lower Jurassic Yongdingzhuang Formation.

Upper Triassic in the north western Henan province have been called Chunshuyao Formation and Tanzhuang Formation (Qi Yong'an et al., 1993; Hu Bin et al., 2000; Zhou Xinke et al., 2005), equivalent There are fewer outcrops in the upper Triassic Xingshikou, Laohugou Formations and contemporary strata, but it can be estimated that the late Triassic basin is mainly zonal distribution, that is, the basin is distributed along Shangyi-Pingquan faults on the south side of Luanping and Chengde. To the east, it can extend to Chaoyang region. In the west of Beijing, it is distributed at NEE along the core of basin. The gravel molasse depositing in the two basin groups is the sediment correspondence for the northside orogen thrust-nappe structure at the same phase, with sediment feature of foreland basin. Similarly, the foreland basin structure is evident in the west segment of south brink of NCC. The foredeep zone is distributed along Shangzhou-Nanzhao in north Qinling, and connects Pingliang Foredeep zone of Ordos basin. to Yanchang Formation in period (Fig. 3c), about 865-1391 m thick, greater than $2500 \mathrm{~m}$ in Mengxian region southwards. In the areas of Jiyuan and Chengliu, the sedimentary facies of Chunshuyao Formation is fluvialswamp deposit with yellowish/ green medium-fine grained sandstone, siltstone, sandy mudstone and mudstone (Chen Chuanshi et al., 1995), with thickness of 485-567m (see Well Jican 1). Including multilayer coal streak, Tuanzhuang Formation is fluvio-lacustrine deposits with yellowish/ grey medium-thick-bedded calcareous siltstone, mudstone, dark mudstone and oil shale, seen in the Well Jican 1 (390 m), Well Deng 5 (Zhang Hongbo et al., 2006). The contemporaneous formations in Luoyang and Yima are called Shifo Formation (Kang Ming, 1988; Yang Shirong, 1994). To the east, the main deposition of upper Triassic in Kaifeng sag is celadon sandstone and mudstone, the top of which develops poor-quality coal seams, coal streak and carbonaceous shale. The fossils combinations are similar with that in the Yanchang Formation. Drilling in Well Tanggu 3 and Well Guangu 2 at Qiuxian 
depression of Linqing depression (Fig. 3d) indicates that the upper Triassic lithologic combinations is similar to that in the Dongming sag of Kaifeng depression (Wang Congfeng, 1987), and middle-late Triassic fossil assemblages developed in this formation (Liu Shaolong, 1986).

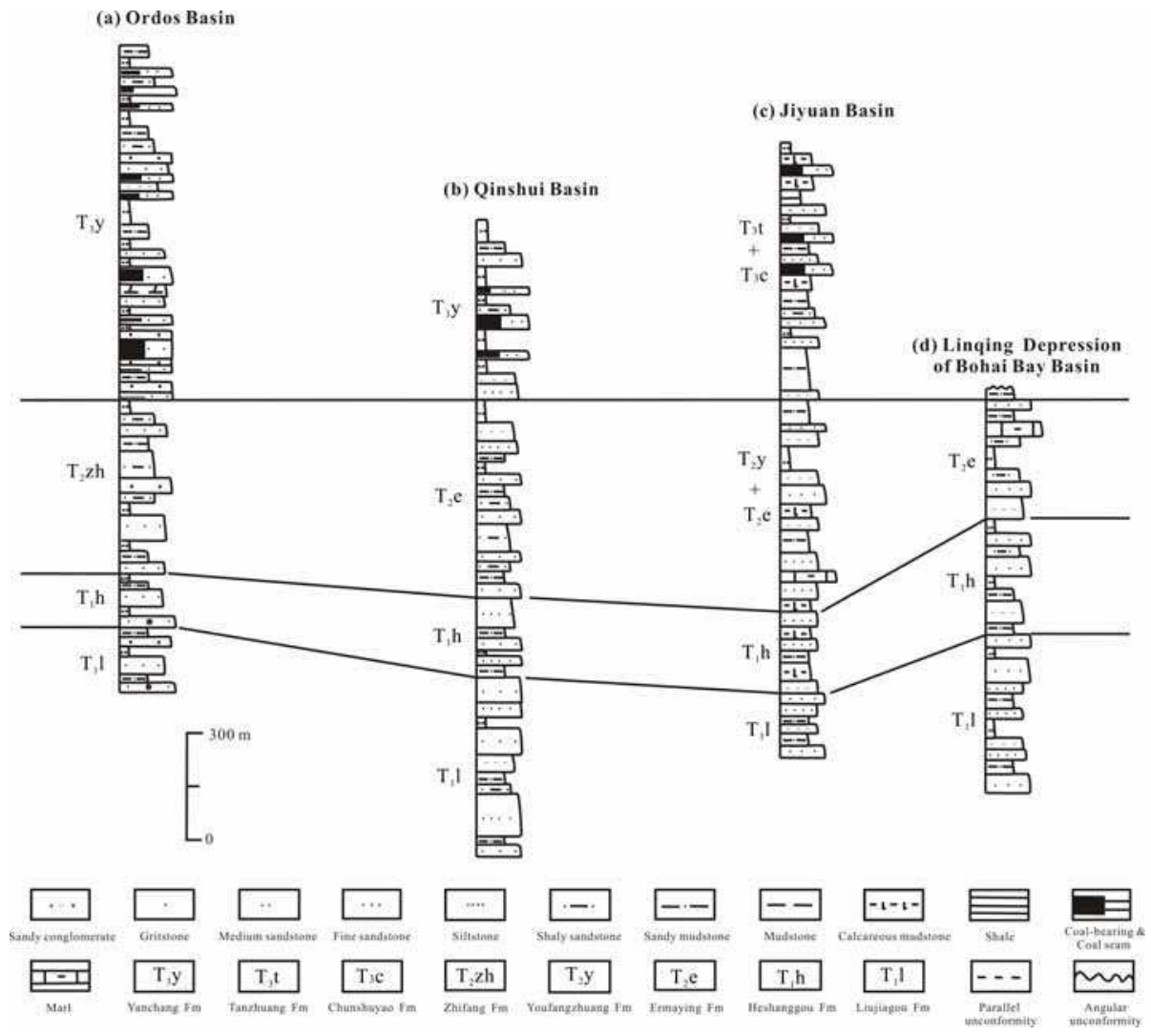

Fig. 3. Sedimentary section of upper Triassic residual formation in intracraton basins of NCC (Section location shown in Fig. 2). a-Ordos basin; b-Qinshui basin; c-Jiyuan basin; dLinqing depression of Bohai bay basin (Changqing oilfield, 1992; Huabei oilfield, 1988; Bureau of geology and mineral resources of Henan province, 1989; Zhongyuan oilfield, 1993).

\subsection{Distribution of late Triassic on the South Edge of NCC}

Based mainly on shallow/ semi-deep lacustrine or delta-fluvial facies, oil shale inclusions in dark mudstone, the upper Triassic of the southern edge appears along Liuyehe river of Zhouzhi, Mangling of Shangxian, Shuanghuaishu, Tanghe river of Lushi, Mashiping, Yahe river of Nanzhao.

The sedimentary facies of lower upper Triassic in Liuyehe river's west section is grayish/ white thick layer of fine quartz-conglomerate, sandy conglomerate, feldspar-quartz sandstone and purple celadon argillaceous-arenaceous slate, $414 \mathrm{~m}$ in thickness; the upper 
part is carbon containing argillites/ sandy slate and medium-fine grained quartz sandstone, feldspar-quartz sandstone interbed, and there is a parallel unconformity between the north side of late Triassic and underlying middle carboniferous; the south side is in fault contact with Mesoproterozoic Qinling Group. The lower part of upper Triassic in Mangling includes slate mixed up with feldspar-quartz sandstone, pebbled sandstone, also developed with siderite nodules and partially with inferior coal. The thickness is greater than $370 \mathrm{~m}$; the upper part is slate mixed up with marl, gritstone and siltstone, with a thickness greater than $780 \mathrm{~m}$, unconformable contacting with underlying Paleozoic, whose fossil plants are the important ingredient of Yanchang flora (Bureau of geology and mineral resources of Shaanxi province, 1989; Yin Hongfu, 1996).

As lacustrine-marsh sediments including coal seam, oil shale and carbonaceous mudstone, the lower part of upper Triassic in the east section, Shuanghuaishu-Tanghe river and Yahe river-Mashiping, is grey fine sandstone and dark grey or black mudstone interbed. The upper part is based mainly on grey/ brown or yellowish/ brown medium-fine grained quartz sandstone and includes fine grained quartz sandstone, black or dark grey mudstone, sandy mudstone. Its sedimentary type is fluvial (Fig. 2). With incomplete outcrops, the formation is gradually thinner from west to east. Its thickness is greater than $1394 \mathrm{~m}$. The thickness of Huangtuling in Mashiping of Nanzhao is greater than $1144 \mathrm{~m}$. eastwards thinning to only $801.5 \mathrm{~m}$ in Dashimen of Fangcheng (Jiaozuo Mining Institute, 1982; Bureau of geology and mineral resources of Henan province, 1989; Zhou Xinke et al., 2005).

\subsection{Distribution of Late Triassic on the North Edge of NCC}

Late Triassic are intermittently distributed throughout Huailai-Zhuolu of northwestern Hebei province, Mt. Xishan of Beijing, Xiabancheng of Chengde-Pingquan in the northeastern Hebei province and Lingyuan-Beipiao in the western Liaoning province (Fig. 4). The formation is called Xingshikou Formation in Huailai-Zhuolu, west Beijing and Chengde; called Dengzhangzi Formation, Laohugou Formation and/ or Yangcaogou Formation in Liaoxi; while called Heishanyao Formation in Funings. The lower part is with grayish/ brown or grey/ purple huge-thick conglomerate and sandy conglomerate. The middle part is with yellow/ white or yellow/ green pebbled sandstone, sandy shale and thin coal seam; The upper part is with blackish/green silty shale and yellowish/ green calcareous fine grained sandstone. And the basal conglomerate has a discordance with middle Triassic in Ermaying Formation or pre-Mesozoic (Yang Nong et al., 1996).

Outcrop of Xingshikou Formation in the west section are distributed in Yaozitou, Chaimulang, Jimingyi, etc. in the northern Hebei province, and is gradually thinning from east to west. Yaozitou is $67.33 \mathrm{~m}$ thick while $19.18 \mathrm{~m}$ thick in Shuiyaogou and $9.4 \mathrm{~m}$ thick in Chaimulang. Further more, the western formation in Jimingyi is only $3.85 \mathrm{~m}$ in the thickness, even thinning out. But in the west of Xiahuayuan, this formation outcrops appear again around Xiajiagou and Wujiagou coal-mine of Zhuolu, and is 7-29.3 m thick (Tian Lifu et al., 1996; Wang Lifeng et al., 1998). Becoming thicker upward, Xingshikou Formation is composed of multiple sedimentary cycles consisting of breccia and silty mudstone. With overlying volcanic rocks in early Jurassic of Nandaling Formation, there is an unconformable contact between this formation and underlying Cambrian, which is gradually transiting to Neoproterozoic from east to west.

The middle segment are distributed in west Beijing and Chengde region, with the thickness of 31-610 m, the lithology of which is grey/ black or khaki shale, silty shale, grey black 


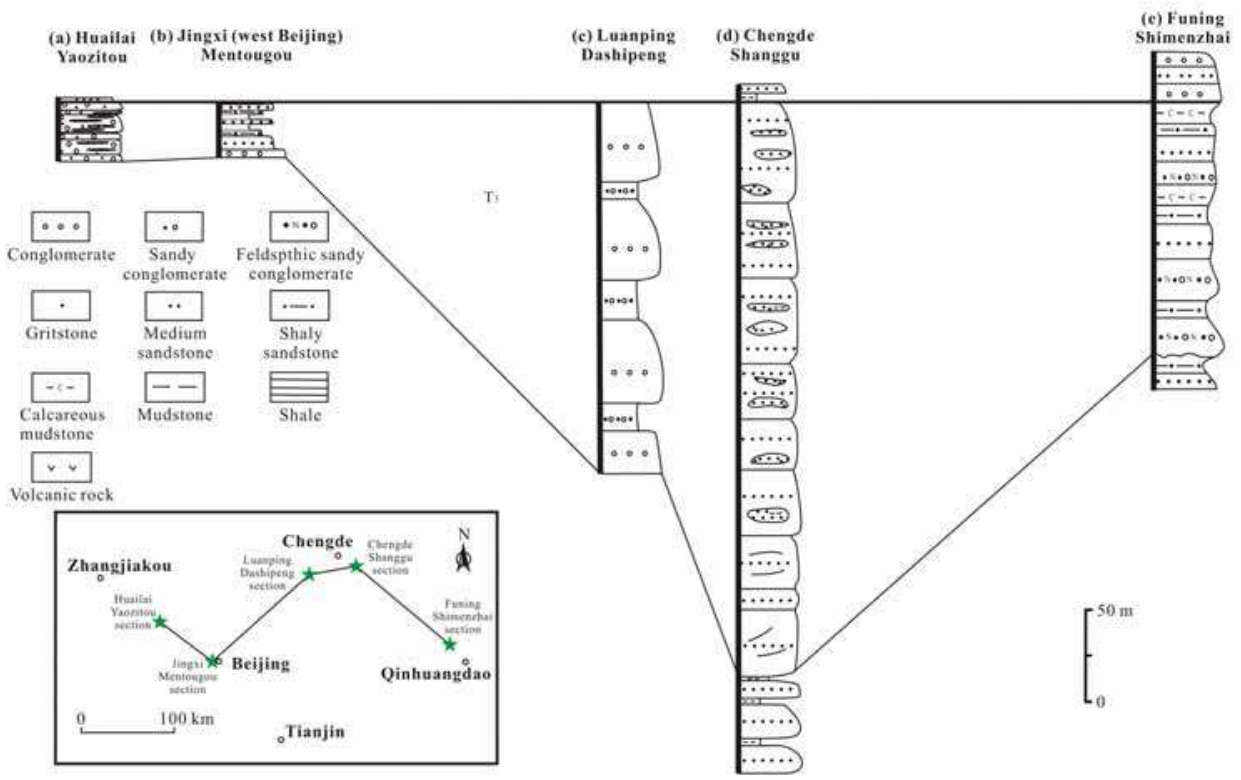

Fig. 4. Profile of late Triassic on the north edge of NCC.

siltstone, sandstone, conglomerate and coal streak, and the sedimentary facies is fluvial (Zhang Jingfang, 2002). The lithology of Dashipeng region in Luanping is yellowish/ brown huge-thick conglomerate with small amount of dust shale, carbonaceous shale, silty shale and includes coal streak. At the same time, the lithology of Wangyingzi Formation is celadon/green gravel-bearing tuff and limestone. And the lower part is black/grey tuffaceous polymictic conglomerate. Transiting to medium-fine conglomerate upward, the upper part of Xiabancheng-Weichanggou in Pingquan is greyish/ brown or grey/ purple huge-thick conglomerate. The middle part is white-yellow or yellowish/green gravelbearing arkose, silty shale. The upper part is yellowish/green silty shale, including yellowish-brown calcareous fine-grained sandstone (Liu Shaofeng et al., 2004; Xu Gang et al., 2006).

Laohugou Formation of east section Niuyingzi basin of Lingyuan in western Liaoning province is yellowish/green siltstone, shale mixed with yellowish/gray medium-coarse grained arkose, gravel-bearing arkose, sandy-cemented fine conglomerate and silty shale. The main lithology of Dengzhangzi Formation is grey thick-layer limestone and dolomitic conglomerate ( $\mathrm{Hu}$ Jianming et al., 2005). Both of them are continuous transitional sedimentary formation (Xu Gang et al., 2003). Laohugou Formation of Jinglingsi-Yangshan basin in Beipiao partially outcrops in the southwestern edge. It is composed of purplish/ red or variegation sandy conglomerate and a few fluvial and lacustrine sandstones (Yan Yi et al., 2003). The contemporaneous formation of Changheying in Beipiao is called Yangcaogou Formation (Wang Xin et al., 2009).

In addition, late Triassic Heishanyao Formation in Funing area of Qinghuangdao is consisted of four sedimentary cycles formed by yellowish/gray or yellowish/green gravel- 
bearing gritstone, fine siltstone and black carbonaceous shale. And its sedimentary facies are delta and lacustrine sediment with thickness of $161.1 \mathrm{~m}$ (Liu Chengzhi et al., 2006).

\section{Regional structural deformation of NCC in late Triassic}

Previous studies are carried out on the tectonic deformation in Indosinian of NCC from different points of views (Huang Jiqing et al., 1977; Ren Jishun et al, 1980; 1990; Cui Shengqin et al., 1983). In late Triassic, large-scale extrusion occurred in the south and north of NCC, which agrees with the EW tectonic line develops in interior craton, and generally shows a tectonic pattern of "ramp" (Zheng Yadong et al., 1990; Zhang Guowei et al., 1995). In interior craton area: (1) the western Ordos area is stable, with slight deformation, and relatively complete residual formation; (2) the eastern area of NCC, with intensive deformation and most of upper Triassic; (3) a major concern is that there exists a transitional belt between the upper Triassic remnant area of Ordos and denudation area in the contemporaneous formation of the eastern North China, but it is feasible to conjecture the deformation and existence of Indosinian movement basing on the "lack" of sedimentary formation or the distribution of late Triassic residual formations and denudation areas as well as the tectonic deformation.

\subsection{Structural deformation of interior NCC in late Triassic}

On the basis of regional tectonic background studies, the N-S collision of late Triassic Yangtze plate and North China plate is in "scissors style", hence NCC is located in a approximate N-S (NNE) compression stress field, the east area began to uplift primarily and extends westward gradually. So the eastern area raised earlier and more intensive while western area raised later and slight. Dabieshan area collided during the end of early-middle Triassic; collision in Sanmenxia area was during the end of middle-late Triassic while the west Qinling collision occurred in the late late-Triassic, therefore Indosinian movement controls the tectonic and sedimentary framework of the south edge of NCC (Xia Bangdong et al., 1996; Wan Tianfeng et al., 2002).

Research on the contact relationship between lower-middle Triassic and overlying formation make it clear that the relationship among Ordos, Qinshui and Jiyuan basins and upper Triassic is conformable or parallel unconformable contact; eastern area is angular unconformity with Jurassic or younger formation, and lower-middle Triassic is eroded in different degree. Jiyang sag lacks Triassic or older formation (Zhu Yanming et al., 2001; di Youliang et al., 2006).

Based on paleo-tectonic reconstruction, NNE-trending uplift and western depression appeared in middle Triassic NCC without upper Triassic in most areas of the east, but synchronous deposition began to develop in western Ordos, Qinshui and Jiyuan basins (Liu Chiyang et al., 1987, 2006; Zhao Zhongyuan et al., 1992). The main part of interior craton deformation area in Ordos is Tongchuan sag after uplift (Fig. 5), which was formed after the uplift. Its north and south sedimentary boundary are limited by northern Qinling and Yinshan separately, and the lake-basin is open tow ard southeast. The late Triassic Yanchang Formation of Qinshui basin is thinner than areas such as Yan'an and Yanchang in the west; marginal facies in upper Triassic of Jiyuan basin does not exist. Yanchang Formation and contemporaneous formations are conjectured to distribute along Datong-ShijiazhuangJinan-Zhoukou (Fig. 2), which is beyond the current basin boundary (Liu Shaolong, 1986; 
Zhao Zhongyuan et al., 1990, 1992; Liu Chiyang et al., 2005, 2007). Such basin pattern is consistent with the research conclusion for ancient compression stress field in Ordos basin, i.e. the NNE-SSW extrusion in Indosinian (Zhang Hong et al., 1996; Xu Liming et al., 2006). As the extension part of southeast area of Ordos basin, NNW-trending Yellow river fault in Luoyang basin of western Henan province moved during early late Triassic and formed Daimeizhai anticline (underwater uplift of Carboniferous-Permian; Chen Chuanshi et al., 1995), the area of Mt. Song rise gradually above the water-level while the southeast area is paleo-Funiu uplift, the water between which is deep and connected with the water area of Yichuan-Linru-Dengfeng. In the last late Triassic, the sedimentary area retreated westnorthward to Mianchi-Yima-Yiyang-Yichuan and was parallel to paleo-Funiu uplift (Zheng Qiugen et al., 1998). The western uplift of Luoyang basin is lack of upper Triassic; the upper Triassic of eastern sag was eroded, and some of the remains are located in the leading edge of Xiashi-Shimen-Wenquanjie thrust nappe, as well as the footwall of Xiashi-Chenzhaigou thrust fault and some of the foreland areas of Xiashi-Shimen- Wenquanjie, Yichuan basin (Fig. 6a).

The western and north edges are lack of upper Triassic; the thickness of intra-basin thicken from northeast to southwest, lacustrine deposits range mostly between 1000-1400 m thick (Changqing oilfield, 1992). The eroded stratum thickness shows the top of Yanchang

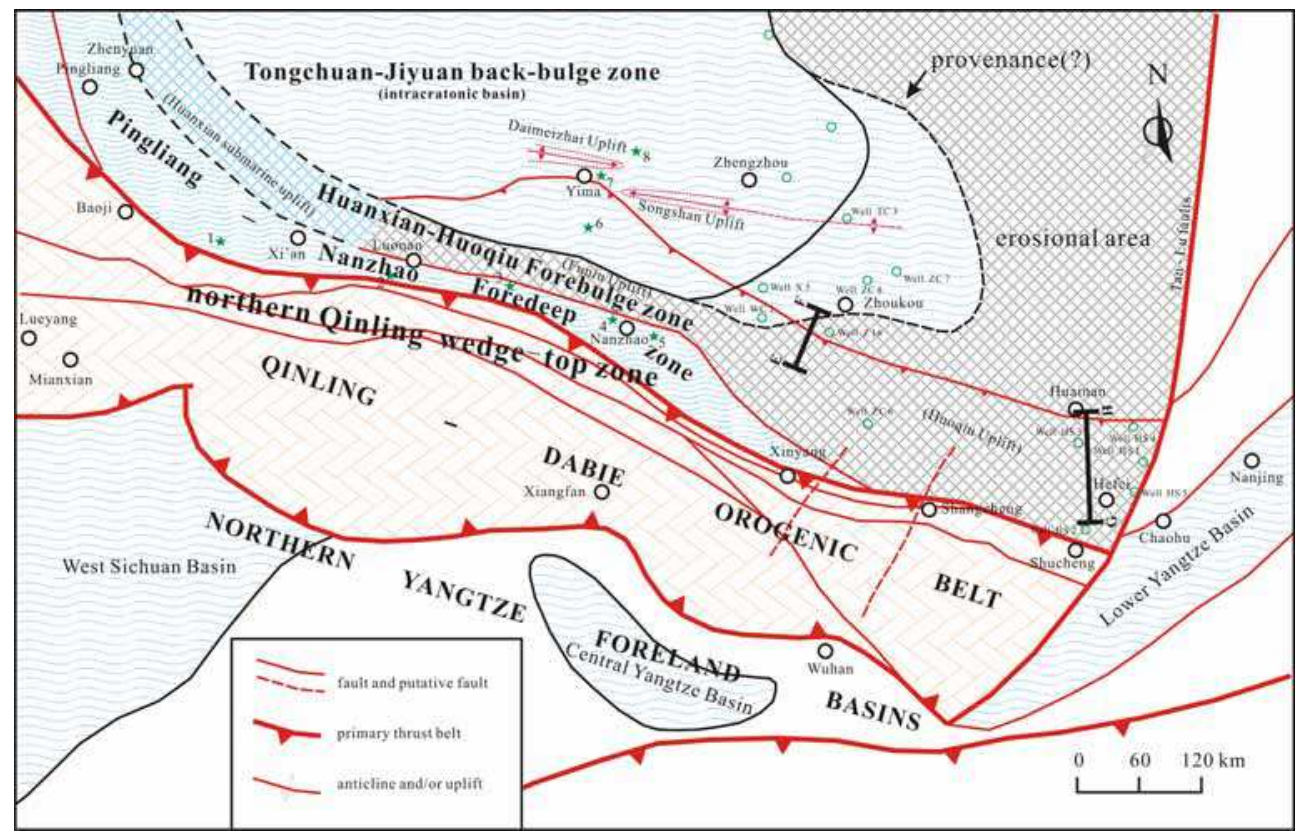

Fig. 5. Regional structure outline map of Indosinian in central-southern part of NCC (Northern Yangtze Plate data is from Xia Bangdong, 1996; Liu Shaofeng et al., 1999; Xu Hanlin et al., 2001; Xu Zhengyu et al., 2004).

Green five-pointed star stands for outcrops: 1-Liuyehe, Zhouzhi; 2-Mangling, Shangxian County; 3Shuanghuaishu, Tanghe river, Lushi; 4-Mashiping, Nanzhao; 5-Yahe river, Nanzhao; 6-Shimen, Songxian County; 7-Miaoyuan, Yima; 8-Chengliu, Jiyuan; Green circles indicate drilling wells. 

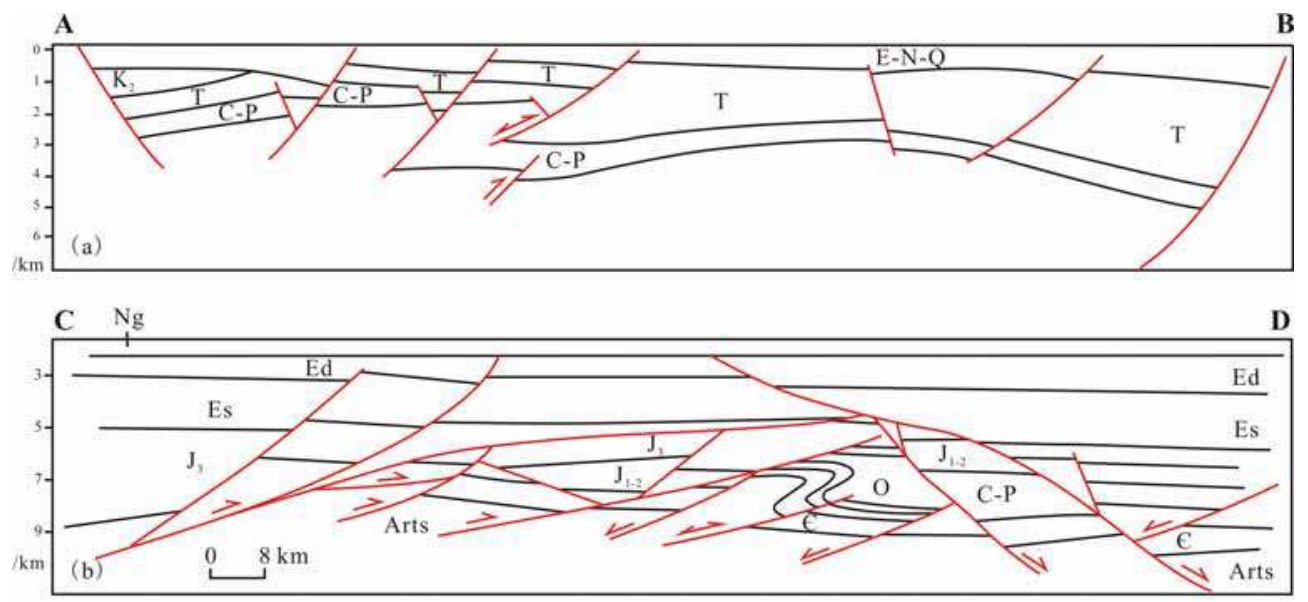

(a) C-P-Carboniferous-Permian; T-Triassic; $\mathrm{K}_{2}$-Upper Cretaceous; E-N-Q-Paleogene-Neogene-Quaternary

(b) Arts-Archean Taishan Group; $\mathcal{C}$-Cambrian; O-Ordovician; C-P-Carboniferous-Permian;

$\mathrm{J}_{1,2}$-Lower-Middle Jurassic Fangzi Fm; $J_{\text {, }}$-Upper Jurassic Mengyin Fm; Es-Paleogene Shahejie Fm;

Ed-Paleogene Dongying Fm; Ng-Neogene Guantao Fm

Fig. 6. Profile of overthrust faults in intra-craton basins of NCC (location shown in Fig. 2, 5).

Formation eroded not too much, while Qingyang-Zhenyuan-Huanxian eroded by about 400 $\mathrm{m}$ and the east of Jingbian eroded less than $100 \mathrm{~m}$ (Chen Ruiyin et al., 2006). Upper Triassic in Qinshui basin is 400-500 m thick; upper Triassic of w estern Henan province was confined in the area of Jiyuan-Luoyang-Yiyang-Dengfeng and in the north of western Kaifeng depression (Bureau of geology and mineral resources of Henan province, 1989; Xu Hanlin et al., 2004). The thicknesses of Jiyuan and Yima are approximately $1700 \mathrm{~m}$. Upper Triassic of Ordos basin thicken from north to south and depositional grain size become finer, but Upper Triassic thinning from north to south in the western Henan province due to Shigouyi and Huating in the south edge of Ordos is the foredeep of foreland basin, while the latter is depression behind of its uplift (Fig. 5).

NCC lack upper Triassic in the eastern area of Datong-Shijiazhuang-Jinan-Zhoukou at present. Although the tectonic deformation during. Indosinian was reformed intensively by Yanshan and Himalayan movements, but their traces still can be found in the EW-trending fold-thrust belts in areas such as Bohai bay basin, Luxi and Xuhuai area. The axis-track of fold in Bohai bay basin was E-W or NEE-trending, and it changed into NNE-trending at the turning in the west of Liaocheng-Lankao fault. For example, the structure of Huanghua depression in Indosinian changed into NEE-trending in the Yanshan orogenic belt (Jin Chong et al., 2007). Western Jiyang depression, Dawangzhuang, Chengbei and Guxi fault zones, as well as Yihezhuang uplift, Chengdong anticline, eastern part of Chezhen sag appear angular unconformity between the low-middle Jurassic and the Palaeozoic (Zong Guohong et al, 1998); Well Zhuanggu 13 shows overturned syncline of CambrianOrdovician in the underlying Jurassic, of which repeated duplication takes place in YeliLiangjiashan Formations. The low-middle Jurassic of Huanghua depression formed an approximate EW-NWW-trending fold-thrust belt (Fig. 6b), the Jianhe syncline, Kongdian anticline and Nandagang-Xuyangqiao synclines developed from north to south. Repetition of Carboniferous-Permian can be seen in Well Konggu 5, repetitions of $22.5 \mathrm{~m}$ and $54 \mathrm{~m}$ in Ordovician are respectively at Well Gang 59 and Well Tai 10. The lower-middle Jurassic 
unconformity of Well Dengcan 1, Well Donggu 1, Wen'an slope of Jizhong depression and Dacheng uplift covers lower-middle Triassic or older formations (Yang Minghui et al., 2005). Wells Wen 5, 10 and 30 in Wuqing sag show the Carboniferous-Triassic repetition and which are covered by lower-middle Jurassic. The seismic sections cross Well Chengbei 20 in Bohai area and its drillings and Well $\mathrm{H} 8$ of Liaoxi low-uplift and Bozhong sag respectively indicate that lower-middle Jurassic appearing as angular unconformity and overlaps of Carboniferous-Permian, Cambrian-Ordovician (Liu Le et al., 2009; Lu Dingyou et al., 2009) and pre-Cambrian metamorphic granite. Indosinian movement appears as lower-middle Jurassic Fangzi Formation with unconformity overlaps of early-middle Triassic or early Paleozoic (Yu Fusheng et al., 2002).

\subsection{Structural deformation in the south edge of NCC in late Triassic}

The foredeep in the south edge of NCC, develop alluvial-fan, delta and deep lacustrine sediments, distributes in Shangzhou-Nanzhao of north Qinling, and connects with Pingliang foredeep of Ordos basin in the west; fore-bulge depozone is composed of Huanxian-Huoqiu basement uplift, back-bulge depozone distributes inside intra-craton basin, and subsidence center is located in Jiyuan-Tongchuan region, in which deeper lacustrine-delta develops. Therefore, the south edge structure of NCC has relative complete "foreland basin system". From south to north, it develops north Qinling wedge-top zone, Pingliang-Nanzhao foredeep zone, Huanxian-Huoqiu fore-bulge zone and Tongchuan-Jiyuan back-bulge zone which forms after uplift (Liu Shaofeng et al., 1999; Chen Shiyue et al., 2000; Yang Minghui et al., 2007, 2009).

In the late Triassic, east section of south edge in NCC develops fold-thrust belt in the north and northern Qinling orogenic belt in the south, bounded by Luonan-Luanchuan thrusting belt. During the movement of south edge fold-thrust belt in NCC, the foredeep zone and even fore-bulge zone are involved in the thrust deformation. Frontal fault belt includes Luanchuan-Gushi-Feizhong faults and Sanmenxia-Lushan-Fuyang-Huainan faults, and ends at Tanlu faults to the east. The frontal fault belt is about $1000 \mathrm{~km}$ long. Along the trending, tectonic segmentation features is stronger in the east segment and weaker in the west segment (Xie Dongning et al., 2006).

According to the research by Guo Xi'nian et al. (1991) and Shi Quanzeng et al. (1990, 2004), the evidences of fold-thrust belt development in western Henan area during the late Triassic can be found including following: (1) fault-belt generally offset Carboniferous-Permian and Triassic, and lateral contemporaneous strata developed a series of miniature NW-trending folds and reverse faults, which are rare in Jurassic; (2) fault plane takes on a group of scratchs which are basically consistent with fault dip; (3) without development of tensile crack; (4) early/ middle Yanshanian granite cuts through local sections, and the angular unconformity of lower Jurassic Yima Formation in Jiyuan and Yima region covers on the upper Triassic Tanzhuang Formation. Lower Paleozoic in the Shanxian-Mianchi coalfield override the Carboniferous-Permian strata and is covered by Jurassic unconformity, . The Mesozoic and Paleozoic in the south part of Yichuan basin override the Triassic may be the result of Indosinian movement (Yu Hezhong et al., 2006). Indosinian thrust and uplifterosion lead southw ard area of Sanmenxia-Fuyang-Huainan faults lacking of Triassic, only with local upper Triassic confined in the Nanzhao foredeep zone (proto-type of foreland basin system), and its east part lacks late Triassic; the west stratum develops but is subject to late-period formation. Separatrix between them is Xiayi-Woyang-Macheng faults which parallels to Tanlu faults (Yang Minghui et al., 2009). 
The thrust strength of Zhoukou depression in the eastern Henan slightly increases and shows in the tectonic pattern of fold-faults (Fig. 7a); thrusting effects get continuously intensive from the eastern part to Huainan region. Archean Wuhe Group in the south edge of Huainan coal basin, Bagongshan Group and Xuhuai Group in Proterozoic, Paleozoic and others thrust and superimposition from south to north to form the imbricate structure (Fig. $7 \mathrm{~b})$. In the south, Hefei basin is located in the foreland of north edge in Dabie orogenic belt, and its basement deformation is characterized by a group of south-inclined thrust faults. For example, nearly E-W-trending Shouxian-Dingyuan, Feizhong, Liu'an, Xinyang-Shucheng faults and so on, which were involved into Permian and previous formations. After the levelling, contact relationship between Indosinian movement of Hefei basin and overlying Jurassic is of angular unconformity (Xu Chuanhua et al., 2002). To the south of Liu'an fault, most of the basement is involved into tectonic deformation, while structure of sedimentary cover is dominant to the north (Zhou Jin'gao et al., 1999; Zhao Zongju et al., 2000). In space, the activity is intensive in the south and the slip rate of Liu'an fault is $225 \mathrm{~m} / \mathrm{Ma}$, which gradually gets weakened northwards (Xu Shihong et al., 2007). The restructure of balanced section shows that the shortening for crust is about $117.8 \mathrm{~km}$ (Zhao Zongju et al., 2001).

E

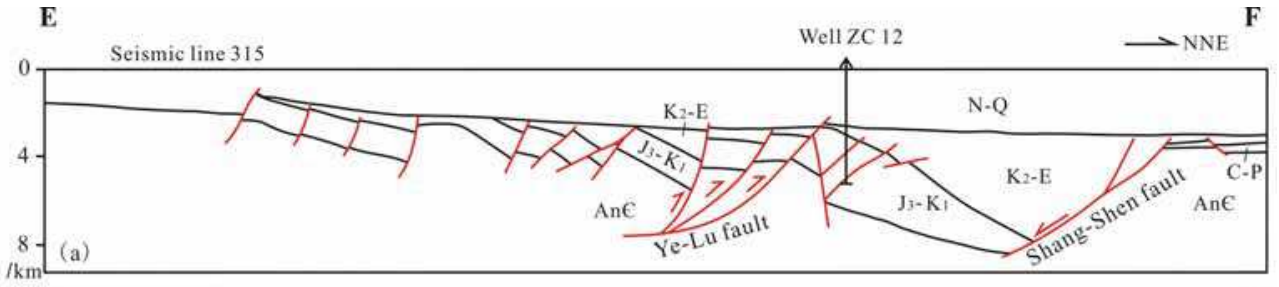

$$
\text { G }
$$

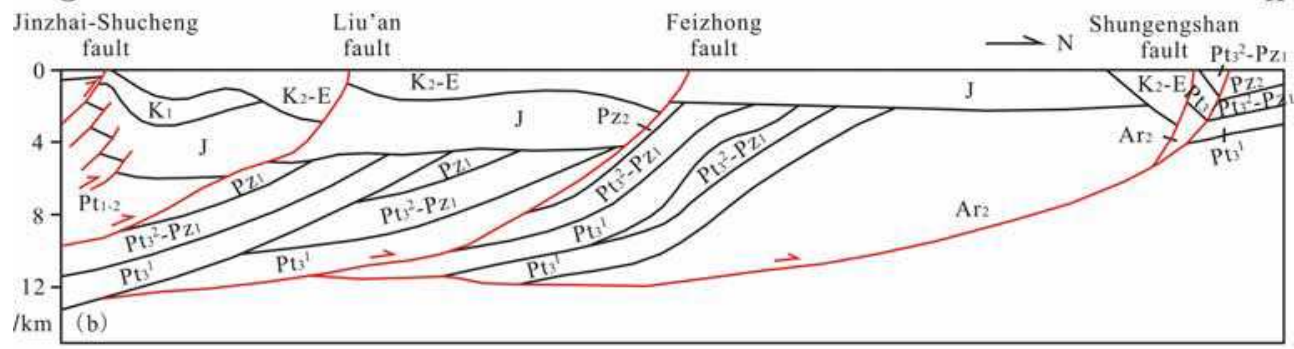

(a) An€-Pre-Cambrian; C-P-Carboniferous-Permian; $\mathrm{J}_{3}-\mathrm{K}_{1}-\mathrm{U}_{\mathrm{p} p e r}$ Jurassic-Lower Cretaceous; $\mathrm{K}_{2}$-E-Upper Cretaceous-Paleogene; N-Q-Neogene-Quaternary; (b) Ar2-Mesoarchean; Pt1-2-Paleo-Mesoproterozoic; $\mathrm{Pt}_{3}^{1}-\mathrm{Q}$ ingbaikou; $\mathrm{Pt}_{3}^{2}-\mathrm{Pz}$-Zhengdan-Lower Paleozoic; PZ2-Upper Paleozoic; J-Jurassic; K 1-Lower Cretaceous; K2-E-Upper Cretaceous-Paleogene

Fig. 7. Profile of overthrusts in South Edge of NCC (location as shown in Fig. 5).

\subsection{Structural deformation of north edge of NCC in late Triassic}

The north edge of NCC originates from the Yinshan in the west and passes through Yanshan to the mountainous land of western Liaoning province, with total length of 1400 $\mathrm{km}$ from east to west. It is approximately located in a complex tectonic belt at $\mathrm{N} 40^{\circ}-42^{\circ}$ from south to north, with basin-and-range terrain and migrant transformation (Wang Guiliang et al., 1999). Mesozoic Yanshan-western Liaoning province is under intra-continental environment. Its orogenic process during Indosinian last from the middle-late Triassic to 
Pre-Jurassic. Pre-Mesozoic NCC put together with the Mongolian block along Soren suture so as to form a typical intra-continental orogenic belt based on craton (Cui Shengqin et al., 2000; Zheng Yadong et al., 2000). In other words, basin deformation in Yanshan and its adjacent regions during Indosinian may show characteristics of intra-continental foreland basin. The late Triassic molasse sediment, distributed on the south side of LuanpingChengde, develops under Shangyi-Pingquan fault and is subject to control by north-south thrust fault (Zhao Yue et al., 1990; Davis et al., 2001). Basin sediment records the uplift and erosion processes on the north side of this faults in Paleozic, Proterozoic and Archean. The molasse with synclinorium distribution along the west of Beijing also related to strong thrust-uplift of basin edge (Liu Shaofeng et al., 2004). After the E-W-trending tectonic belt was overlaid by NNE tectonic belt, present tectonic framework comes into being.

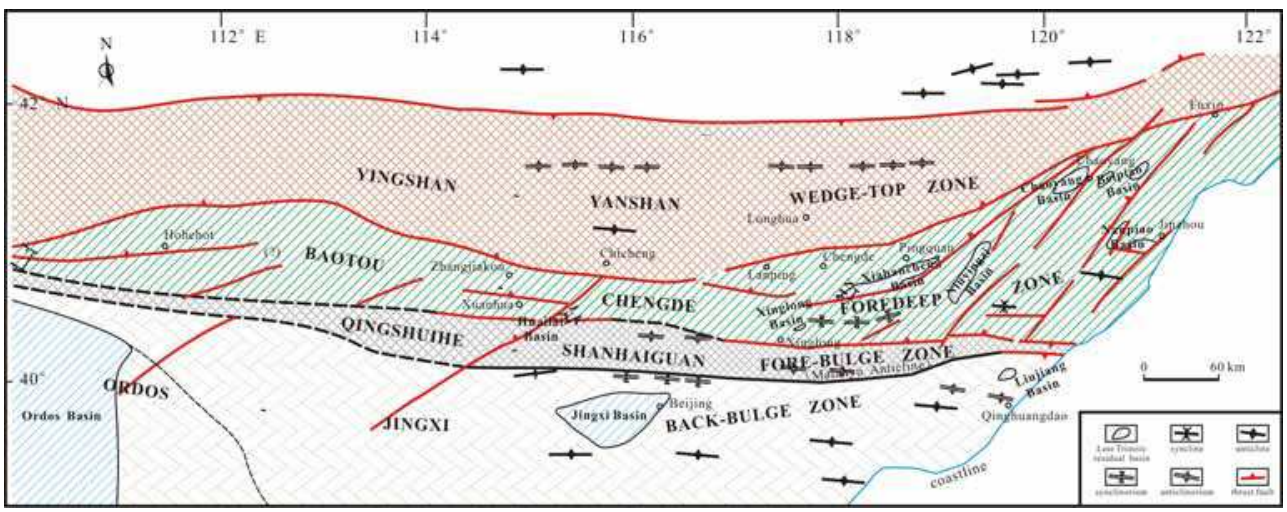

Fig. 8. Tectonic outline map of north edge of NCC in late Triassic.

Indosinian deformation in the north edge of NCC can be traced to Mt. Daqing in Inner Mongolia (in the north of Ordos basin) and China-Mongolia border region in the west, which appears as a S-N compression and forms a series of complex folds and associated overthrusting nappes which are distributed in the $\mathrm{E}-\mathrm{W}$ direction. Based on the research by Zheng Yadong et al. (1990, 2005), the north nappe in napping tectonics of China-Mongolia border is composed of Neoproterozoic and Mesoproterozoic dolomitic limestone mixed with quartz sandstone. South nappe is involved in tillite of Sinian and black siliceous slate in early Cambrian, with overall napping directs at $180^{\circ}$ (Fig. 9a). The wide and gentle synclines are composed of coal series of Wudanggou Fromation in Jurassic under Shiguai basin of Mt. Daqing, and its east part is reformed by Yanshanian nappe structure and shows as rockslices cover upper Jurassic Daqingshan Formation. Regional survey implies that Baihugou and Sharqin region in the south part of basin develop grayish/ white basal conglomerate with middle-thick base-layers in Wudanggou Formation covering lower Triassic-Paleozoic with angular unconformity, as well as thrusts associated with folds. The length of such unconformity is $4 \mathrm{~km}$ and inclines northwards. Wudanggou Formation in Baotou city covers lower Triassic Miaogou Formation with angular unconformity of Miaogou region, where occur weathering crust and basal conglomerate. This illustrates that this region underwent late Triassic uplift erosion and subsidence and deposited again in early Jurassic (Liu Zhenghong et al., 2003). 

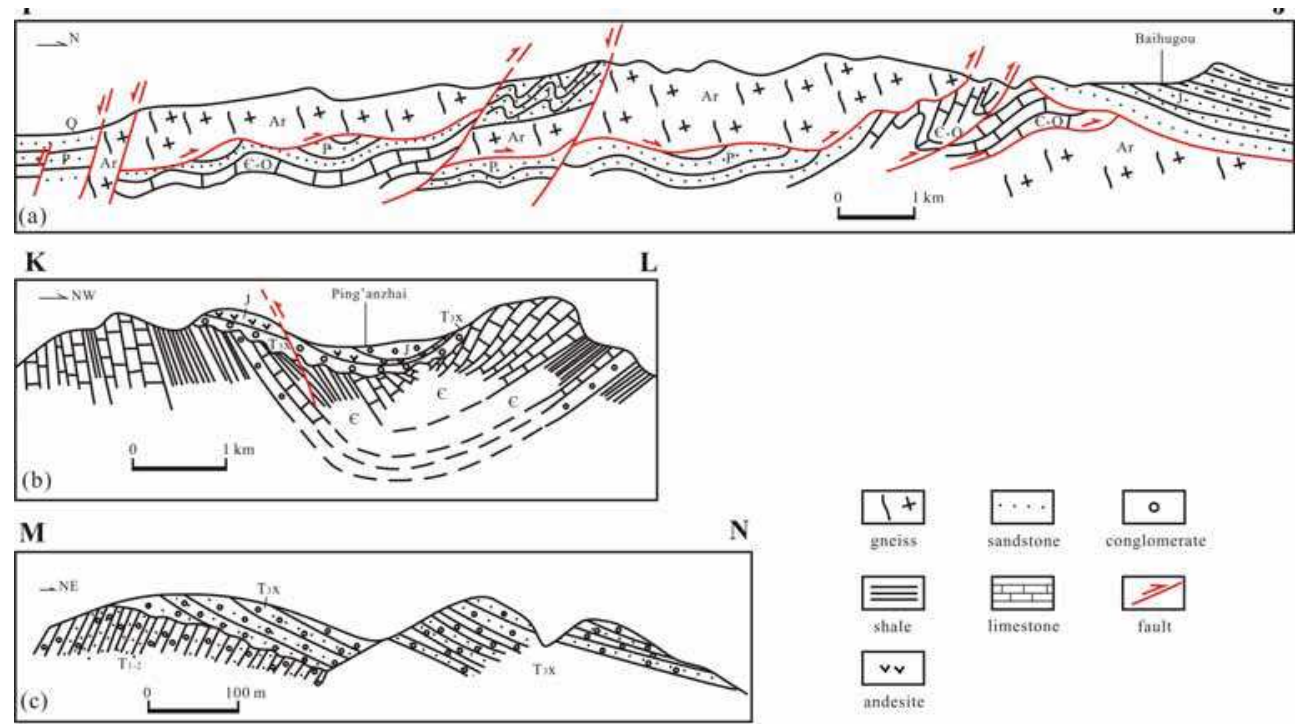

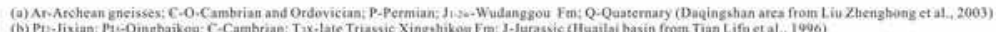

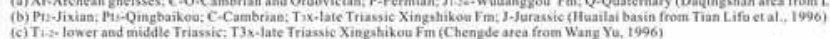

Fig. 9. Profile of thrust-nappe structure in north edge of NCC (location as shown in Fig. 8).

Beijing-Chengde and western Liaoning, located in east part of north edge of NCC, develop upper Triassic Xingshikou Formation, Laohugou Formation and so on. This indicated that there existed the difference of ancient geological environment from east to west, and the tectonic movement of the west part was earlier and stronger than that in the east part. To the west of Beijing, Xingshikou Formation is only distributed on the west side of ShanghuangqiWulonggou faults and Huairou-Laishui faults. To the east of Beijing develop Xingshikou Formation and its underlying lower-middle Triassic sediment. In the early Indosinian, Xiahuayuan region developed EW-trending Guchengliang fault (Wang Shide, 1987), to the east of which Xingshikou Formation is distributed in the east of Jimingyi, with thickness increasing westwards, even almost disappear when close to erosion area (Wang Lifeng et al., 1998). The Ping'anzhai syncline core of E-W-trending consist of Xingshikou Formation, early Jurassic Nandaling Formation and Xiahuayuan Formation, while the flanks consist of Jixian, Qingbaikou and Cambrian, with northern flank gentle and southern one steep (Zhang Yong, 2006). According to the studies by Xiao Zongzheng et al. (1995), Indosinian movement in Beijing shows as E-W fold-fault, such as Gujishan anticline and Huiyu syncline, etc. Based on stratigraphic sequence and contact relationship, the huge and thick quartz conglomerate develop on the bottom of Xingshikou Formation (Baozhudong Conglomerate) and overlaps above different strata in different area. Its underlying formation gradually decreases from Badachu, Mt. Xishan in Beijing to Baoershui, with contact relationship is micro-angular unconformity or disconformity. Lithofacies belt, stratigraphic isopach and coal streak in Yaopo Formation of Julongshan syncline in north and east Hebei are E-W or nearly E-Wtrending, evidently, controlled by Indosinian E-W folds (Chen Ruiqi, 1982).

The unconformity contact on the bottom of Xingshikou Formation was formed during Indosinian in Chengde, where develop later Triassic small basins along fold-thrust belt under uplift background (Fig. 9b). Upper Triassic deposited in the synclines area based on 
base deformation feature. Sedimentary construction shows the lower part of upper Triassic is alluvial and fluvial sediments, which play a role of basin-filling. The gravels of Xingshikou Formation in Dashipeng region are very well sorted and rounded. They are the products of volcanic activity in the vicinity region (Zhang Jinfang, 2002). Li Zhong et al. (2003) find the provenance comes from orogenic belt on the north side, and paleocurrent direction of conglomerate in Xingshikou Formation is at $168^{\circ}$ as the middle part of Yanshan is higher in the north and lower in the south.

To the east, late Triassic small basins develop in west Liaoning, such as Chaoyang, Jianchang and Beipiao basins, etc. Due to strong tectonic uplift and extrusion in the later Triassic, the angular unconformity between lower Jurassic Beipiao Formation and upper Triassic Laohugou Formation occur in Chaoyang basin (Zhang Guoren, 2006). Late Triassic basin in Laohugou region of Lingyuan disappears, sedimentary hiatus appears between lower Jurassic and upper Triassic (Ma Yinsheng, 2001). The NE fault belt with NW incline in Niuyingzi basin in Lingyuan, which controls the sediment during late Triassic Dengzhangzi Formation deposition (Fig. 9c). Some faults are covered by middle Jurassic Guojiadian Formation. The squeezing lenticle and scratches indicate the thrusts from NW to $\mathrm{SE}$ ( $\mathrm{Xu}$ Gang et al., 2003). K-Ar isotopic dating shows the age of consequent layer diabase prophyrite intruding into Mesoproterozoic-Neoproterozoic is 243.4-199.4 Ma, in Indosinian period (Wang Genhou et al., 2001).

\section{Proto-basin type of North China basin in late Triassic: Discussion on intra- craton basin edged by foreland basin of South and North Brinks}

In early-midle Triassic, NCC still remains as a unified basin. In late Triassic, Yangtze plate collided with North China plate (Xia Bangdong et al., 1996). South edge of NCC was extruded nearly S-N, and ancient Qinling ocean closed. Then QDOB formed. In the north edge, late Paleozoic NCC collided with Siberia plate (Xu Bei et al., 1997). Therefore, between Yangtze plate and Siberia plate, the south edge of late Triassic NCC was actively extruded by Yangtze plate, and the north edge was relatively fixed limited boundary. On the both sides, thrust-nappe structure and frontal intra-continent foreland basin develop. Since late Triassic, the east part of hinterland started uplift. The east part of NCC lacks upper Triassic and suffered from serious erosion, and strata under laid by Jurassic became older and older from west to east. Contemporaneous sedimentary basin retreats southwestwards until turn back into Ordos basin, but still keep stead state as Paleozoic-early Mesozoic intra-craton basin (Fig. 10) (Liu Chiyang et al., 2006).

\subsection{Characteristics of intra-continental foreland basin in the north edge of NCC}

YYOB extends to the westward region of Baotou from north to west, with the length of is $1100 \mathrm{~km}$. The tectonic line of middle-west segments in this belt strikes dominantly nearly $\mathrm{E}-$ $\mathrm{W}$, while the tectonic line of eastern segments in this belt features NNE-NE. And the west part of south edge of YYOB is Mesozoic Ordos basin which is stable, and the east part is covered by late Mesozoic-Cenozoic Bohai bay basin. Mt. Yinshan in the north edge of NCC exists during Indosinian. But the later tectonic movement, contemporaneous foreland basin disappeared gradually because of deformation. Residual intra-continental foreland basin is mainly distributed in west Beijing, Chengde and west Liaoning, called as "west BeijingChengde basin" and "Liaoxi basin" (Wang Guidong et al., 1992; Li Zhong et al., 2003; Ma Yinsheng et al., 2003; Liu Shaofeng et al., 2004). 

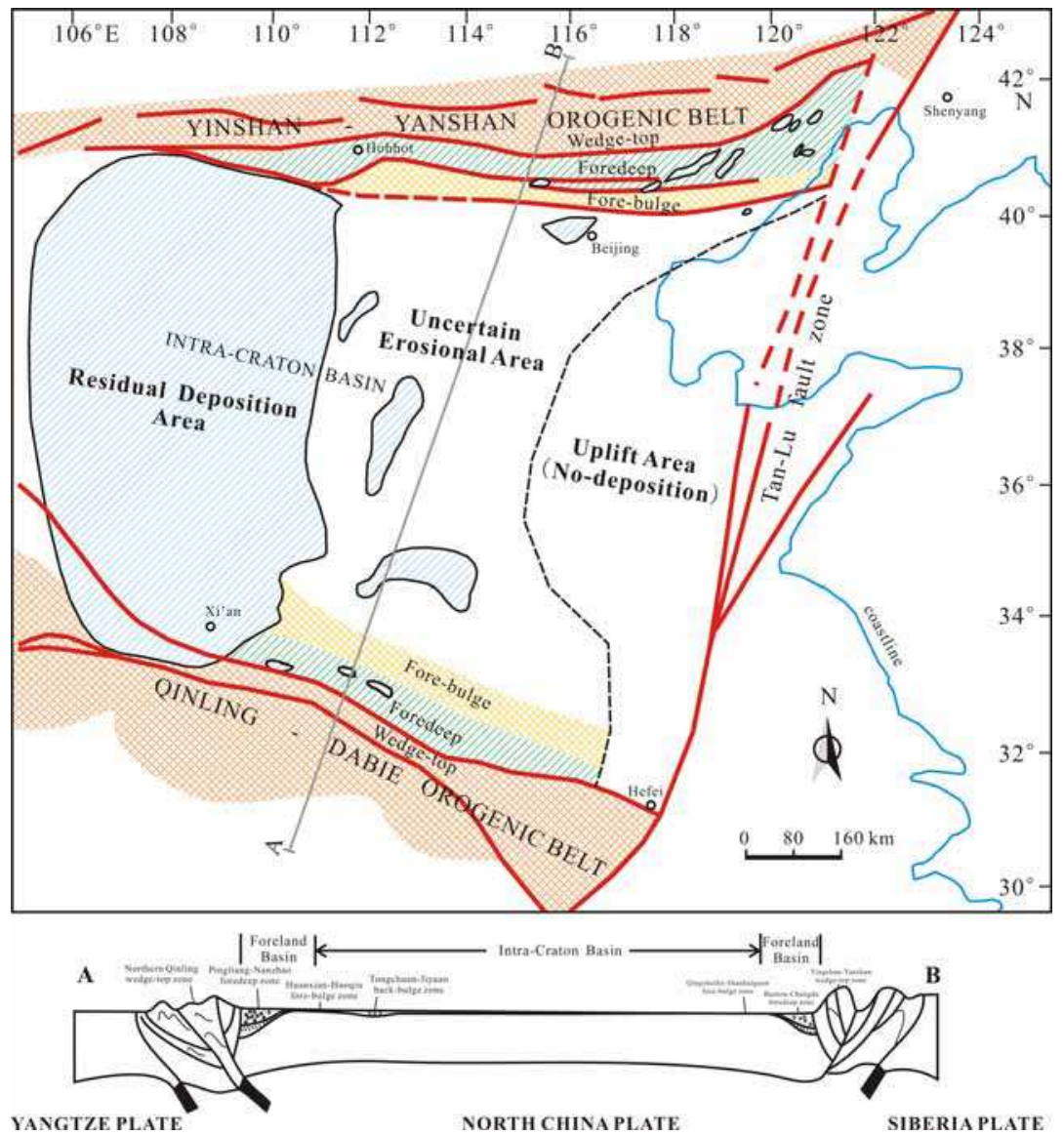

Fig. 10. Distribution pattern map of late Triassic sedimentary basin in NCC.

From north to south, distributed along the north edge of Triassic molasse conglomerate, an N-S overthrust nappe fault develops at the north side of Shangyi-Pingquan faults, controlling the formation of conglomerate zone (Zhao Yue, 1990; Davis et al.,2001). More than ten small-sized remnant basins are confined in the south of this fault and mainly distribute over partly-deformed upper Mesoproterozoic-middle Triassic in the southward region of this fault. On the north side, there is mainly Archean-Palaeoproterozoic crystalline rock. Later, both two sides are covered widely by late Jurassic-Cretaceous volcanicsedimentary rock. Shangyi-Pingquan faults links with Lingyuan-Donggongyingzi thrust fault in west Liaoning, which is mainly manifested as Archean or Proterozoic thrust above Mesozoic.

Upper Triassic Xingshikou Formation is mainly distributed along the core of west BeijingChengde basin and extends westwards to the region around Chaoyang, west Liaoning. On the cross section, basin filling, in wedge shape, shows that subsidence center of the basin is located on north side and sedimentary thickness and coarse clastic contents at north side or northwest side are more than those on the sourth side or southeast side. With slight 
directional alignment, Xingshikou Formation of Shanggu region in the core of Chengde basin is a set of thick-layer conglomerates. According to the measurement for flat surface of imbricate conglomerates, paleocurrent direction is mainly southward and partly northward. With the sedimentary type of gravelly braided channel, this set of conglomerates is basin margin facies. And Xingshikou Formation conglomerates are slightly rounded and directional in west Beijing basin. Direction of paleocurrent may be from east to west according to few measurements of oblique bedding. Based on the analysis on fragmentary composition and depositional filling polarity characteristics of basin, associated with the formation of nearly EW dispersed linear basin groups, from Mt. Yanshan and Liaoning to north Yinshan region, "Inner Mongolia axis of earth" was ever strong uplifting area, with parallel trend to it. And it becomes the main source of contemporaneous sediments. At the same time, according to the analysis of early-middle Jurassic coal-bearing strata and reverse profile characteristics of late Jurassic detrital composition, there may exist early-middle Jurassic (late Triassic) strata with certain scale before the uplift of late Jurassic on "Inner Mongolia axis of earth", which also was denudated in the strong uplift process of late Jurassic (He Zhengjun et al., 1999). As a whole, Xingshikou Formation is the sedimentary response of strong thrust uplifting in provenance area (Liu Shaofeng et al., 2004).

Most of researchers have accepted that the north part of NCC developed a series of thrust nappe structure during Mesozoic. But the formation time and activity intensity have remained to hang in doubt. As mentioned above, there is coupling relationship in time \& space between these thrust nappe structures and intra-continental foreland basin developing $\mathrm{E}-\mathrm{W}$ in late Triassic. There is obvious genetic relationship between both. According to geological scale, the sedimentary accumulation including lots of coarse clastic constituents have the nature of syngenesis generally. And there are some corresponding relations between conglomerate layers and episodic tectonic phase (Jordan et al., 1988; Burbank et al., 1988; Chen Haihong et al., 1992). In late Triassic, because of ever-increasing thrust loading, the lithosphere in frontal edge of thrust nappe structure presented flexural subsidence, and then formed linear depression basin groups. Therefore, the polarity filling characteristics and huge thick coarse accumulation of late Triassic basin in the north part of NCC responded to the strong nappe-uplift event during the same period.

\subsection{The characteristics of intra-continental foreland basin in the south edge of NCC}

From the perspective of regional tectonics of east Asia, NCC, Yangtze plate and south Qinling micro-plate are all miniature plates between Euroasian plate and Gondwana Land. In Hercynian, inconsistencies of paleomagnetic polar-wander curve existed among them, but they moved to the north as a whole. During late Triassic-early Jurassic, polar-wander curve tended to be uniform and indicated that they combine together. Most importantly, Yangtze plate and NCC presented large-angle horizontal-rotation that Yangtze plate rotated clockwise and NCC rotated anticlockwise (Wu Hanning et al., 1990; 1992; Liu Yuyan et al., 1993). In terms of the geological evolution, Qinling ocean closed in the late Triassic; NCC spliced with Yangtze plate; Collisional orogeny of Qinling-Dabie comprehensively launched (Zhang Guowei et al., 2001) and ushered in intra-continental orogenic stage (Sengor, 1985; Wang Qingchen, 1989; Li Shuguang et al.,1998). In time \& space sequence, the development and evolution of foreland basin in the south edge of NCC and QDOB are very identical. Because of "scissors" collision effect among plates, the foreland basins in south edge of NCC have the characteristic of east-west differentiation. 


\subsubsection{Foreland basin system in the south edge of Ordos basin}

Bridging over the current Weihe garben and north Qinling region, the south edge of Ordos basin can reach the north side of Shangdan suture, with a large sedimentation range. The ancient geographical landscape of Ordos basin was higher in the north and lower in the south, the water-body was shallower in the north and deeper in the south, and deposition was thinner in the north and thicker in the south. All of these asymmetric depression properties show that the development and extension of sedimentary facies belt of south edge of Ordos basin is controlled by the compression and uplift of Qinling orogenic belt. The lacustrine sediment opens westwards and spreads nearly EW-NWW, with the same extension direction of Qinling orogenic belt. The research shows that the foreland basin system in the south edge of Ordos basin is still well preserved nowadays (Liu Shaofeng et al., 1999; Chen Shiyue et al., 2000; Yang Minghui et al., 2007).

The thickness of foredeep zone stratum of south edge foreland basin system can be over $3000 \mathrm{~m}$. In the late Triassic, because of the steep terrain, adjacency to the lake basin, short distance for sediment transport and rapid accumulation, the foreland of overthrust structure of Qinling orogenic belt crossed the foredeep to Mt. Kongtong and other regions, and developed such regions into braided -delta such as Ruishui River-Zhenyuan, the edge of the basin developed into small-scale alluvial fans such as Kongtong Mountain-Mawugou. Conglomerate in Mt. Kongtong comes from Sandaogou in Pingliang, and belongs to marginal facies (Zhao Wenzhi et al., 2006). Braided-delta deposit mainly contains gravelly sand and gritstone, and rock debris content decreases northeastwards. Rock debris which reflects the provenance is from the granite, gneiss and carbonate distribution area in Qinling orogenic belt in the southwest part.

The middle-south part of Ordos basin is a depression belt spreading northwestwards, which is steeper in the south and gentler in the north, and steeper in the south and shallower in the north, i.e., Tongchuan-Jiyuan back-bulge zone. The thickness of Yanchang group is generally more than $1100 \mathrm{~m}$; and the thickness of the south part is more than $1400 \mathrm{~m}$. This back-bulge zone is also the main part of intra-craton basin, with gentle northeast flank, steep southwest flank and opening eastwards. The north edge of basin can reach northwards of Hangjinqi-Dongsheng region, extend eastwards to the west Henan and interior NCC and end in the west Mt. Taihangshan. The isopach map of late Triassic prepared by Zhao Hongge et al. (2007) shows the basin has the characteristics of higher north part and lower southwest and southeast parts on the whole. The thickness of Kongtong-Ruishuihe in foredeep zone of southwest edge can reach up to $3000 \mathrm{~m}$. In the west Huanxian-Tongxin region, there is a low-uplift zone spreading nearly $\mathrm{NW}$, with about $500 \mathrm{~m}$ relative thin sedimentary strata on it, which is the contemporaneous fore-bulge zone. The uplifts are covered directly by early-middle Jurassic Yan'an Formation in Mt. Yao, Mt. Tan, Well Yan 11, Huan 26 and other places, which demonstrates that it is the underwater uplift in deposition. The average thickness of intra-craton basin is less than $1300 \mathrm{~m}$, thickest area located in Ansai-Tongchuan region, EW spread and thickening eastwards.

\subsubsection{The destroyed foreland basin in south edge of southern North China basin}

Because of intensive Indosinian thrust-nappe and uplift erosion, the southward region of Sanmenxia-Lushan-Fuyang-Huainan faults basically lacks Triassic, while thin upper Triassic clastic rocks containing coal only exist in the foredeep zone of Nanzhao region in the western Henan. It indicates that this is a destroyed foreland basin system. Beihuaiyang 
structural belt in east segment of north edge, Hefei basin and Huainan region develop Indosinian thrust-nappe structure. Although differences in terms of tectonic pattern and strength exists, it forms a unified Indosinian nappe structure and produces nearly EWtrending fold-thrust belt which has the basically consistent direction with spread direction of QDOB, and forms tectonic pattern of interphase uplift-depression (Zhao Zongju et al., 2000). Lushi region of the western Henan in west section and Beihuaiyang structural belt are located in the same tectonic position. Undeformed upper Triassic sandy conglomerate contacts directly with the south-inclined Zhuyangguan-Xiaguan ductile shear zone, the direction of lithofacies spread is controlled by regional tectonics. The southern stratum is thicker than north, and such strata overlap northwards above Erlangping complex with the characteristics of "piggy back" deformation in foreland region.

During Indosinian, Beihuaiyang structural belt was located in the trailing edge of thrustnappe structure. Based on balanced cross-sections recovery, the crust was shortened by 120 $\mathrm{km}$, which occupied 86\% of the whole shortening for Mesozoic-Cenozoic (Cao Gaoshe et al., 2003). According to the combined data of drilling, outcrops, seismic section, interval velocity and MT, a series of nearly EW-trending faults are developed in the south of Hefei basin, such as Gushi-Hefei fault, Shushan fault, Feixi-Hanbaidu fault and Shucheng fault. These faults were shown as slopes in different sizes during Indosinian, and the bedding faults were shown as flat. Upper detachment surface may partly disappear due to later erosion. The northern crystalline basement of Hefei basin is uplift, and overlying Paleozoic cover has been mostly eroded in some areas, with slight the tectonic deformation of remnant sedimentary cover. Therefore, Beihuaiyang structural belt and Hefei basin are involved in deformation of fold-thrust belt, and forward brink reaches into the south side of Huainan region. The core of Huainan syncline includes Carboniferous-Permian and lower Triassic, and the deformation isn't involved into Mesozoic and Cenozoic (Yan Kongde, 1989). It is the Indosinian product. Coalfield exploration data shows that thrust tectonics develop on both side of Huainan syncline. On south side, Shungengshan fault thrusts northwards as the main thrust surface, and it reforms the pre-Mesozoic in varying degrees. On north side, it takes Nanjie fault of Bengbu uplift as the main thrust surface, and the fault thrusts southwards in pre-Mesozoic (Shen Xiuzhi et al., 1995), which forms triangle belt tectonics.

To the west, except southern and northern border fault of NWW, the size of intracontemporaneous fault is smaller in Xinyang basin. To the west of Xinyang, the thrustnappe system of Maoji region is involved into the latest stratum, which is middle-lower Triassic containing radiolarian fossils, and the system is also invaded by middle-acid rockbody of middle-late Yanshanian (Du Yuansheng et al., 1997; Guo Hua et al., 2002). The thrust-nappe in Zhoukou depression is covered by the late sediment, but seismic section shows that Cambrian-Ordovician thrust structure makes overthrust above the Carboniferous-Permian and covered by Jurassic. The strength and size of thrust fault in Zhoukou depression are smaller. Its tectonic pattern is wide and gentle fold, and some early-middle Triassic sediments may exist in syncline region.

\section{Discussion \& conclusions}

\subsection{Stratigraphy of NCC in late Triassic}

The residual stratigraphic succession of NCC in late Triassic has the characteristics of subareas: (1) Western Ordos in the interior-craton develps completely, to the southwest of which is the deposition and subsidence center of the basin. Upper Triassic strata extend 
eastwards to central Shanxi province and western Henan province in the hinterland of the basin, which are distributed in vast, continuous stretches. (2) In the north part of NCC, there is solitary distribution of the upper Triassic along west Liaoning-west Beijing-north Hebei. (3) In the southern part of the NCC, upper Triassic strata develop along north Qinling in west Henan-south Shaanxi area. Strata at the southern and northern edges of NCC are involved in late orogeny deformation, and now present like fragments between thrust faults.

\subsection{Structural deformation of NCC in late Triassic}

A tectonic-magmatic active belt formed during late Paleozoic is located in the northern Yanshan and western Liaoning province from east to west. The magmatic rock belt may be formed along the active continental side on the south of Soren suture when Siberia plate collided with NCC in Permian. During Mesozoic, NCC was developed in an intracontinental tectonic environment, which was a preexisting tectonic condition of YanshanLiaoning intra-continental orogeny deformation. In late Triassic, the northern NCC and Siberia plate collided and linked, making the paleo-Asian ocean disappear. On the south side, NCC collided with Yangtze plate, forming QDOB. QDOB formed earlier (during late middle Triassic) than Okhotsk structural belt in the north. Therefore, in late Triassic, the S-N compression on the north and south sides of NCC formed a "colliding" over-thrust tectonic pattern on the whole, which corresponded with WE striking structural belts pre-existed in intra-craton. In interior NCC, there is regional tectonic stability in Ordos basin in the west, which shows strata are better preserved with minor deformation. And there is strong deformation in the east, without upper Triassic. The boundary line of the two different areas runs approximately along Datong-Shijiazhuang-Ji'nan-Zhoukou.

\subsection{Tectonics of proto-basin types in NCC}

Analysis on syn-depositional structure records is very important for studying the process of regional structure deformation. Syn-depositional structure records keep the information of uplift, denudation and sediment process which are jointly controlled by deformation and other factors during the process of structure deformation in the geologic history. NCC region suffers from great reform due to Yanshan and Himalayan movements after the Triassic. And other questions have always been the hotspots under discussion. From the perspective of lithology, the remaining lower-middle Triassic can be tracked and contrasted from west to east, showing the same sediment background in the west and east of the NCC. From the perspective of lithofacies features, marginal facies sediment in the lower-middle Triassic are absent in many places. So it can be inferred that the area of proto-basin of NCC during the lower-middle Triassic should be more extensive than the current remaining area. In the late Triassic, NCC changes significantly. Firstly, the sediment boundary shrank compared with that in the early-middle Triassic. According to remaining distribution of the upper Triassic, the boundary was only limited in the western-southern region, including Ordos, middle and south Shanxi, west Henan, as well as Yanshan-Liaoning and north Qinling on the south and north sides. Secondly, the western and northern brinks of Ordos basin lack the upper Triassic, and marginal facies sediment develops in west-south brink; the late Triassic sediment is commonly absent in the east Bohai bay basin; the upper Triassic distribution in the southern North China is confined in Jiyuan region. All above explain that the late Triassic boundary of NCC retreated back to the west. The lower, middle and upper 
Triassic in Ordos, Qinshui and Jiyuan basin are in conformity and unconformity contacts. Hence, the proto-basin of the west NCC in the late Triassic is inherited craton basin which overlaps the early-middle Triassic basin.

For the Mesozoic basin in the west of Beijing and Yanshan-Liaoning, because of prophase and anaphase structure reform and multiphase basin superposition and denudation, most of original patterns of the basin have been destroyed and divided into many small basins. In order to find out the sedimentary paleogeography, evolution and the relationship with tectonic effect, the late Triassic proto-basin is restored through extensively sediment section observation and contrast, paleocurrent measurement, gravel component contrast and structure deformation analysis. The upper Triassic Xingshikou, Laohugou Formations and time-equivalent strata has fewer outcrops, but can be infered to distributed in belt along Shangyi-Pingquan faults on the south side of Luanping and Chengde, extend eastward to Chaoyang region, and NEE striking distributed along the core of basin in the west of Beijing. The typical gravel molasse deposition in the two basin groups is correspondence for the north-side orogen thrust-nappe structure, with characteristics of intracontinental foreland basin. Similarly, the structures in the foreland basin are evident in the west segment of south brink of NCC. The foredeep zone is distributed along Shangzhou-Nanzhao in north Qinling, and touch Pingliang Foredeep zone of Ordos basin in the west. The foredeep zone consists of alluvial fan, delta and deep lacustrine deposit system. The fore-bulge zone is constituted by the basement uplift of Huanxian-Huoqiu. The back-bulge zone is distributed in NCC intra-basin, and subsidence center lies in Jiyuan-Tongchuan where deep lacustrine -delta system develops. "Foreland basin system" is reflected by north Qinling wedge-top zone, Pingliang-Nanzhao foredeep zone, Huanxian-Huoqiu Fore-bulge zone and TongchuanJiyuan back-bulge zone from south to north.

\section{References}

[1] Burbank D W, Raynolds R G H. 1988. Stratigraphic keys to the Timing of Thrusting in Terrestrial Foreland Basins: Applications to the Northwestern Himalaya. In: Kleinsphn K L, Paola C (eds.), New Perspectives in Basin Analysis. Springer-Verlag New York Inc., 331-351

[2] Darby B J, Davis G A, Zheng Y, et al. 2001. Structural evolution of the southwestern Dagingshan, Yinshan belt, Inner Mongolia, China. GSA Mem, 194: 199-214

[3] Davis G A, Zheng Yadong, Wang Cong, et al. 2001. Mesozoic tectonic evolution of the Yanshan fold and thrust belt, with emphasis on Hebei and Liaoning Provinces, northern China. In: Hendrix M S, Davis G A, eds. Paleozoic and Mesozoic tectonic evolution of central Asia: From continental assembly to intracontinental deformation: Boulder, Colorado, Geological Society of America Memoir 194, 2001. 171-197

[4] Gao S, Rudnick R L, Carlson R W, Mc Donough W F, Liu Y S. 2002. Re-Os evidence for replacement of ancient mantle lithosphere beneath the North China craton. Earth and Planetary Science Letters, 198: 307-322

[5] Griffin W L, Zhang A D, O. Reilly S Y, Ryan G. 1998. Phanerozoic evolution of the lithosphere beneath the Sino-Korean craton. In: Flower M, Chung S L, Lo C H, Lee T Y, eds. Mantle dynamics and plate interactions in East Asia. Washington DC: American Geophysical Union, Geodynamic Series, 27: 107-126 
[6] Jordan T E, Flemings P B, Beer JA. 1988. Dating Thruse-fault activity by use of forelandbasin strata. In: Kleinsphn K L, Paola C (eds.), New Perspectives in Basin Analysis. Springer-Verlag New York Inc., 307-330

[7] Menzies M A, Fan W M, Zhang M. 1993. Palaeozoic and Cenozoic lithoprobes and the loss of $>120 \mathrm{~km}$ of Archaean lithosphere Sino-Korean Craton, China magmatic processes and plate tectonics. In: Pritchard H M, Alabaster T, Harris N B W, Neary C R, Eds. Magmatic processes and plate tectonics. Geological Society London, 76: $71-81$

[8] Menzies M A, Xu Y G.. 1998. Geodynamics of the North China craton. In: Flower M, Chung S L, Lo C H, Lee T Y, Eds. Mantle dynamics and plate interactions in East Asia. Washington DC: American Geophysical Union, Geodynamic Series, 27: 155165

[9] Xu Yigang. 2001. Thermo-tectonic destruction of the Archaean lithospheric keel beneath eastern China: evidence, timing and mechanism. Physics and Chemistry of the Earth (A), 26: 747-757

[10] Cao Gaoshe, Li Xuetian, Liu Deliang, Zhou Songxing, Gao Yijun. 2003. Indosinian nappe structure and its hydrocarbon significance in Hefei basin and north Huaiyang tectonic zone. Oil \& Gas Geology, 24(2):116-122

[11] Cao Hongxia. 2008. Research on the rule of depocenter migration and evolution of Late Triassic in Ordos basin. A doctoral dissertation submitted to Northwest University, $1-134$

[12] Chen Chuanshi, Su Xianbo. 1995. Fault-block movement and evolution of the Jiyuan basin during the Mesozoic. Sendimentary Facies and Palaeogeography, 15(1):18-23

[13] Cheng Haihong, Sun Shu, Li Jiliang, et al. 1992. Tectonic constraint of foreland basin. In: $\mathrm{Li} \mathrm{J} \mathrm{L}$. Research on the structure and evolution of the land-sea lithosphere in Southeast of China. Science and Technology of China Press, Beijing, 17-31.

[14] Chen Ruiyin, Luo Xiaorong, Chen Zhankun, Wang Zhaoming, Zhou Bo. 2006. Estimation of denudation thickness of Mesozoic stata in the Ordos basin and its geological significance. Acta Geological Sinica, 80(5): 685-693

[15] Chen Shiyue. 2000. Sedimentary tectonic evolution from Late Palaeozoic to Triassic in the South of North China block. Journal of China University of Mining \& Technology, 29(5): 536-540

[16] Cui Shengqin, Li Jinrong, Sun Jiashu, Wang Jianping, Wu Zhenhan, Zhu Dagang. 2000. Sequence of tectonic movements and regional tectonic framework in the north edge of North China block. Geology Press, Beijing, 1-326.

[17] Cui Shengqin, Li Jinrong. 1983. On the Indosinian movement of China's Peri-Pacific tectonic belt. Acta Geological Sinica, 57(1): 51-62

[18] Deng Jinfu, Mo Xuanxue, Zhao Hailin, Luo Zhaohua, Du Yangsong. 1994. Lithosphere Root/ De-Rooting and activation of the East China continent. Geoscience--Journal of China University of Geoscience, 8(3):349-356

[19] Deng Xiuqin, Lin Fangxiao, Liu Xianyang, Pang Jinlian, L Jianwen, Li Shixiang, Liu Xin. 2008. Discussion on relationship between sedimentary evolution of the Triassic Yanchang Formation and the Early Indosinian movement in Ordos basin. Journal of Palaeogeography, 10(2):159-166 
[20] Du Xudong, Xue Linfu, Wu Guanghui. 1999. Distribution of Mesozoic basin and discussion geodymics of continent interior in the Eastern China. Journal of Changchun University of Science and Technology, 29(2):138-143

[21] Du Yuansheng, Yin Hongfu, Wang Zhiping. 1997. The late Caledonian-Early Hercynian basin's framework and tectonic evolution of Qinling orogenic belt. Earth Science, 22(4):401-405

[22] Fu Jinhua, Guo Zhengquan, Deng Xiuqin. 2005. Sedimentary facies of the Yanchang Formation of Upper Triassic and petroleum geological implication in southwestern Ordos basin. Journal of Palaeogeography, 7(1):34-44

[23] Guo Hua, Wu Zhengwen, Liu Hongxu, Wang Runhong. 2002. The overthrust-nappe tectonic framework of Yanshan intraplate orogenic belt. Geoscience, 16(4): 339-346

[24] Guo Hua, Wu Zhengwen, Chai Yucheng, Feng Ming. 2002. Mesozoic overthrust-nappe tectonic system in the Dabieshan orogenic belt. Geoscience, 16(2): 121-129

[25] Guo Xinian, Tang Zhonglin, Li Wancheng. 1991. Late Paleozoic coal accumulating regularities in Henan province. Wuhan: China University of Geosciences Press, 156167

[26] He Zhengjun, Wang Zongqi, Ren Jishun. 1999. A preliminary research on sedimentary features and genetic mechanism of frontal basins before Jurassic large-scale Nappe in the Northern Region of North China. Scientia Geologica Sinica, 34(2):186-195

[27] Bureau of Geology and Mineral Resources of Henan Province. 1989. Regional geology in Henan province. Beijing: Geology Press

[28] Hu Bin, Huang Changchun. 2000. The types of fluvial deposits and its ichnofabric feature from the Upper Triassic epoch of Jiyuan basin. Western Henan. Henan Geology, 18(3):176-180

[29] Hu Jianmin, Liu Xiaowen, Xu Gang, Liu Jian, Zhang ShuanHong. 2005. The sliddingslump-mudflow sedimentation during the Late Late-Triassic to Middle Jurassic in Western Liaoning Province. China. Acta Geologica Sinica, 79(4):543-564

[30] Ji Youliang, Hu Guangming, Huang Jianjun, Wu Zhiping. 2006. Eroded strata thickness of Mesozoic and evolution of Mesozoic and Cenozoic basins in the Bohai Bay basin area. Acta Geologica Sinica, 80(3):351-358

[31] Jia Shixun, Zhang Xiankang. 2005. Crustal structure and comparison of different tectonic blocks in North China. Chinese Journal of Geophysics, 48(3):611-620

[32] The Studying Team of Mesozoic, Jiaozuo Mining Institute. 1982. The Mesozoic coalbearing formations division and comparison in Henan. (Internal Report)

[33] Xie Dongning, He Mingxi, Zhou Lifa, Xie Qifeng. 2006. Characteristics of overthrust structures on northern edge of East Qinling-Dabie orogenic belt and hydrocarbon potentials. Oil \& Gas Geology, 27(1):48-55

[34] Jin Chong. 2007. Structural pattern, evolution and dynamic mechanism of the Mesozoic strata in the Huanghua depression and Jiyang depression. A masteral dissertation Submitted to Ocean University of China, 1-70.

[35] Kang Ming. 1988. Mesozoic coal-bearing strata of Yima, Henan. Journal of Stratigraphy, (2):81-92

[36] Li Hongyan, Xu Yigang, Huang Xiaolong, He Bin, Luo Zhenyu, Yan Bin. 2009. Activation of north edge of the North China Craton in Late Paleozoic: Evidence from $\mathrm{U}-\mathrm{Pb}$ dating and $\mathrm{Hf}$ isotopes of detrital zircons from the Upper Carboniferous 
Taiyuan Formation in the Ningwu-Jingle Basin. Chinese Science Bulletin, 54(5):632640

[37] Li Shuguang, Nie Yonghong, Liu Deliang, Zheng Shuanggen. 1998. Interaction between subducted continental crust and the mantle-I. Major and trace element geochemistry of the syncollisional mafic-ultramafic intrusions in the Dabie Mountains. Science in China,Ser.D,

[38] Li Shuguang, Nie Yonghong, S.R.Hart, Zhang Zongqing. 1998. Interaction between subducted continental crust and the mantle -II. Sr and Nd isotopic geochemistry of the syncollisional mafic-ultramafic intrusions in Dabie Mountains. Science in China,Ser.D,

[39] Li Shuangli, Ouyang Ziyuan. 1998. Tectonic framework and evolution of Xing'anling Mongolian Orogenic Belt (XMOB) and its adjacent region. Marine Geology \& Quaternary Geology, 18(3):45-54

[40] Li Wenhou, Pang Jungang, Cao Hongxia, Xiao Li, Wang Ruogu. 2009. Depositional system and paleogeographic evolution of the late Triassic Yanchang Stage in Ordos Basin. Journal of Northw est University (Natural Science Edition), 39(3):501-506

[41] Li Zhong, Dong Renguo, Zheng Jianpin. 2007. Mesozoic volcanic-sedimentary configurations in north and south edges of the eastern North China Craton: Implications for tectonic transition mechanism. Journal of Palaeogeography, 19(3):227-242

[42] Li Zhong, Li Jiwei, Sun Su, Zhang Wenhua. 2003. Mesozoic basin-fill records in south foot of the Dabie Mountains: Implication for Dabie Orogenic attributes. Science in China, Ser.D,

[43] Liu Chiyang. 2007. Geologic characteristics and petroleum accumulation conditions of superimposed basin. Acta Petrolei Sinica, 28(1): 1-7

[44] Liu Chiyang, Zhao Hongge, Gui Xiaojun, Yue Leping, Zhao Junfeng, Wang Jianqiang. 2006. Space-Time coordinate of the evolution and reformation and mineralization response in Ordos Basin. Acta Geological Sinica. 80(5):617-638

[45] Liu Chiyang, Zhao Hongge, Wang Feng, Chen Hong. 2005. Attributes of the Mesozoic structure on the west margin of the Ordos Basin. Acta Geologica Sinica, 79(6):738747

[46] Liu Chiyang. 1987. The tectonic evolution of Bohai Bay Basin and its characteristics. In: Collection on thesis of academic report conference for the $45^{\text {th }}$ anniversary of the College of Geology, Northwest University. Xi'an: Shaanxi Science and Techology Press, 447-458

[47] Liu Le, Yang Minghui, Li Chunxia, Zheng Xiaofeng. 2009. Fractured reservoirs in metamorphic buried-hills in the Liaoxi low uplift and their hydrocarbon accumulation conditions. Oil \& Gas Geology, 30(2):188-194

[48] Liu Shaofeng, Li Sitian, Zhuang Xinguo, Jiao Yangquan, Lu Zongsheng. 1996. Simulation of the subsidence and deposition of the foreland basin on the southwestern margin of Ordos. Acta Geologica Sinica, 70(1):12-22

[49] Liu Shaofeng, Li Zhong, Zhang Jinfang. 2004. Evolution and tectonic regime of the Mesozoic basins inYanshan area. Science in China, Ser.D, 34(zI):19-31

[50] Liu Shaofeng, Yang Shigong. 1997. The north-south difference and its formation mechanism in the west margin of Ordos Basin. Scientia Geologica Sinica, 32(3):397408 
[51] Liu Shaofeng, Zhang Guowei, Chen Shunyou, Yao Anping. 1999. Evolution of flexural basins and process of collision orogeny in East Qinling-Dabie Shan and its adjacent regions. Scientia Geologica Sinica, 34(3):336-346

[52] Liu Shaolong. 1986. The existence of a large-scale Triassic Sedimentary Basin in North China. Acta Geological Sinica, 60(2):128-138

[53] Liu Zhenghong, Xu Zhongyuan, Yang Zhensheng. 2003. Indosinian tectonic movement in the Daqingshan Region in Inner Mongolia. Geological Review, 49(5):457-463

[54] Liu Chengzhi, Ma Fengrong. 2006. The guide book for geological practice in the Beidaihe region. Beijing: Petroleum Industry Press, 80-84

[55] Lu Fengxiang, Zheng Jianping, Li Wupin, Chen Meihua, Yu Chunmei. 2000. The main evolution pattern of Phanerozoic mantle in the Eastern China: the "Mushroom Cloud" model. Earth Science Frontiers, 7(1):97-107

[56] Lu Fengxiang, Zheng Jianping, Shao J'an, Zhang Ruisheng, Yu Chunmei. 2006. Asthenospheric upwelling and lithospheric thinning in late Cretaceous-Cenozoic in eastern North China. Earth Science Frontiers, 13(2):86-92

[57] Lu Dingyou, Yang Minghui, Zhou Xinhuai, Wei Gang, Liu Le, Li Chunxia, Zheng Xiaofeng. 2009. Structural characteristics and hydrocarbon accumulation in the buried-hills of the Liaoxi low-uplift, the Liaodong Bay Depression. Oil \& Gas Geology, 30(4):490-496

[58] Liu Yuyan, Yang Weiran, Morinaga Hayaom, Adachi Yasuhisa, Yonezawa Takafumi, Yaskaw a Katsumi. 1993. Paleogeographic history of North China continental block, Qinling geological block and Yangtze continent block since the Paleozoic Era. Geological Science and Technology Information, 12(4): 17-21

[59] Liu Yuyan, Yang Weiran, Morinaga Hayaom, Adachi Yasuhisa, Yonezawa Takafumi, Yaskaw a Katsumi. 1993. Some paleomagnetic results on North China, Qinling and Yangtze blocks. Earth Science-Journal of China University of Geosciences, 18:635641

[60] Ma Yinsheng. 2001. The evolution of Mesozoic-Cenozoic basin-mountain structure in the east Yanshan area and Xialiaohe basin. Journal of Geomechanics, 7(1):79-91

[61] Qi Yong'an, Su Xianbo. 1993. Trace fossils of Late Triassic meandering river sedimentary and their meanings, Jiyuan, Henan. Henan Geology 11(2), 119-122

[62] Qiu Ruizhao, Deng Jinfu, Zhou Su, Li Jinfa, Xiao Qinghui, Wu Zongxu, Liu Cui. 2004. The lithosphere type in the North China: Evidences on geology and geophysics. Science in China, Ser.D:34(8):698-711

[63] Ren Jishun. 1990. On the geotectonics of Southern China. Acta Geological Sinica, 64:275288

[64] Ren Jishun. 1994. The continental tectonics of China. Acta Geoscientia Sinica, (3-4): 5-13

[65] Ren Zhanli, Xiao Hui, Liu Li, Zhang Sheng, Qin Yong, Wei Chongdao. 2005. Fission track evidences of tectonic-thermal evolution history in Qinshui basin. Cinese Science Bulletin, 50(z1): 87-92

[66] Shanxi bureau of geological and mineral. 1989. Regional geology in Shanxi province. Beijing: Geology Press, 673-674

[67] Shen Xiuzhi, Xue Aiming, Liu Deliang, et al. 1995. Relationship between tectonics and gas in basins, south of the North China. Hefei: University of Science and Technology of China Press 
[68] Shi Quanzeng, Shang Yuzhong, Pang Jiqun, Tao Ziqiang. 1990. The nappe structure and distribution of coal field in the north slope of East Qinling Mountain, Henan province. Henan Geology, 8(4): 22-34

[69] Shi Quanzeng, Wei Xiangdong, Li Mingli, Pang Jiqun. 2004, The nappe structure and the strike-slip shear structure in the north edge of East Qinling Mountain, Henan province. Beijing: Geology Press, 15-101

[70] Tian Lifu, Hu Huabin, Hu Shengjun,Yang Zusen, Zhu Caifa. 1996. Discussion on the Indosinian Movement in the Western Yanshan Range. Journal of Shijiazhuang University of Economics, 19(6): 668-672

[71] Tian Lifu, Sun Liming, Hu Huabin, Zhou Pinwei, Hu Shengjun. 1996. Establishment of the Xingshikou Formation and its stratigraphic significance in the Western Yanshan Ranges. Journal of Shijiazhuang University of Economics, 19(6): 724-728

[72] Wan Tianfeng, Zhao Weiming. 2002. On the Mechanism of intraplate deformation in Chinese Continent. Earth Science Frontiers, 9(4): 451-463

[73] Wang Congfeng. 1987. Discovery of the Late Triassic strata in the North Henan Plain. Journal of Stratigraphy, (1): 48-52

[74] Wang Genhou, Zhang Changhou, Wang Guosheng, Wu Zhengwen. 2001. Tectonic framework of Western Liaoning Province and its evolution during Mesozoic. Geoscience, 15(1): 1-7

[75] Wang Guiliang, Yan Shouxun, Jiang Bo. 1992. The compound extension structure system of Meso-Cenozoic in West Shandong Province. Journal of China University of Mining \& Technology, 21(3): 1-8

[76] Wang Guiliang, Liu Guijian, Zouhai, Li Chaofeng, Wang Jiyao. 1999. Coupling and transition of the Mesozoic basin mountain on the northern edge of North China Platform and its dynamics analysis. Coal Geology \& Exploration, 27(6): 14-17

[77] Wang Lifeng, Zhou Pinwei, Hu Shengjun. 1998. The Late Triassic alluvial fan of Huailai county, Hebei and its structural environment. Journal Geology \& Mineral Resources North China, 13(3): 230-235

[78] Wang Quan, Liu Xueya, Li Jinyi. 1991. Plate tectonics between cathaysia plate and angara paleo-landmass. Beijing: Press of PKU: 74-91

[79] Wang Qingchen, Sun Shu, Li jiliang, Zhou Da, Kenneth J. Hsu, Zhang Guowei. 1989. The tectonic evolution of the Qinling Mountain belt. Chinese Journal of Geology, (2): $129-142$

[80] Wang Shide. 1987. Tectonics of Jiming Mountain and Yudai Mountain in XiaHuayuan Area. Journal of Hebei Geology College, (2): 1-15

[81] Wang Xin, Li Nan, Wang Yongdong, Zheng Shaolin. 2009. Discovery of huge complete cycads fossils in Upper Triassic strata, Western Liaoning and its significance. Chinese Science Bulletin, 54(13): 1937-1939

[82] Wang Yi, Lu Kezheng, Ren Anshen. 1994. Tectogenesis and volcanism and the basin evolution of the Mesozoic era in the Northeast of Jiyang depression. Journal of The University of Petroleum, China, 18(2): 1-8

[83] Wei Wenbo, Ye Gaofeng, Jin Sheng, Deng Ming, Jing jian'en, Peng Zhiqiang, Lin Xin, Song Shilei, Tang Baoshan, Qu Shuanzhu, Chen Kai, Yang Honhwei, Li Guoqiang. 2008. Geoelectric structure of lithosphere beneath eastern North China: features of a thinned lithosphere from magnetotelluric soundings. Earth Science Frontiers, 15(4): 204-216 
[84] Wu Fuyuan, Sun Deyou. 1999. The Mesozoic magmatism and lithospheric thinning in Eastern China. Journal of Changchun University of Science and Technology, 29(4): 313-318

[85] Wu Hanning, Zhu Rixiang, Liu Chun, Chang Chengfa. 1990. Paleomagnetic observations in Norht China block: from Late Paleozoic to Triassic. Chinese Journal of Geophysics, 33(6): 694-701

[86] Wu Hanning, Zhu Rixiang, Liu Chun, Chang Chengfa. 1990. Paleomagnetic study on the Danfeng group ophiolite in Qinling area and its tectonic significance. Seismology and Geology, 12(1): 79-85

[87] Wu Hanning, Chang Chengfa, Liu Chun, Zhong Dalai. 1990. Evolution of Qinling fold belt and the North and South China blocks: The evidence of Geology and Paleomagnetism. Chinese Journal of Geology, (3): 201-214

[88] Wu Hanning, Chen Yan, Zhou Dinwu. 1992. A preliminary paleomagnetic result of the Danfeng ophiolite formation of the Shangdan zone in the Qinling belt (China). Chinese Journal of Geophysics, 35(3): 361-368

[89] Xia Bangdong, Li Peijun. 1996. Sedimentologic evidence on the Docking of Yangtse Plate and North China Plate in Middle-Late Triassic Epoch in East China. Acta Sedimentologica Sinca, 14(1): 12-21

[90] Xiao Yuanyuan, Ren Zhanli, Qin Jiangfeng. 2007. Geochemistry and Zircon LA-ICP MS $\mathrm{U}-\mathrm{Pb}$ Dating of the Zijinshan Alkaline Complex in the Linxian County, Shanxi Province: Geological implication. Geological Review, 53(3): 433-440

[91] Xiao Zongzheng, Yang Honglian, Shan Qinsheng. 1995. On some Mesozoic geological problem in Beijing area. Journal of Stratigrphy, 19(4): 308-314

[92] Xing Zuoyun, Xing Jishan, Zhao Bin, Liu Jianhua, Yuan Xiaoping. 2006. Identification of Deep Structure of two episodes in North China and its significance-Yanshanian Movement and Deep Process. Geological Review, 52(4): 433-441

[93] Xu Bei, Chen Bin. 1997. The structure and evolution of the Middle Paleozoic orogenic belt between North China plate, north of Inner Mongolia and Siberia Plate. Science in China, Ser.D, 27(3): 227-232

[94] Xu Chunhua, Qiu Liangui, Lei Min, Li Xuetian. 2002. The evolution of the Dabie orogenic belt based on the sedimentary styles and tectonic patterns of the Hefei basin, Anhui. Sedimentary Geology and Tethyan Geology, 22(2): 91-98

[95] Xu Gang, Zhao Yue, Gao Rui, Li Qiusheng, Hu Jianmin, Liu Xiaowen, Wu Hai, Yang Fuquan, Zhang Shuanhong, Guan Ye, Zhang Jisheng, Bai Jin, Kuang Chaoyang, Wang Haiyan. 2006. Mesozoic basin deformation of Yanshan folded Fault BeltRecords of the intraplate deformation process: A case study of Xiabancheng, Chengde-Shangbancheng and Beitai Basins. Acta Geoscientica Sinica, 27(1): 1-12

[96] Xu Gang, Zhao Yue, Hu Jianming, Zeng Qingli, Liu Xiaowen, Wu Hai, Song Biao. 2003. Late Triassic thrusting in the Niuyingzi region, Western Liaoning, China. Acta Geologica Sinica, 77(1): 25-34

[97] Xu Hanlin, Feng Shiqi, Zhu Hongfa, Shen Yang, Zhao Ping. 2001. Formation and evolution of Late Triassic-Middle Jurassic foreland basins' tectonic framework in South China. Marine Origin Petroleum Geology, 6(1): 19-26

[98] Xu Hanlin, Zhao Zongju, Lu Fuliang, Yang Yilin, Tang Zuwei, Sun Guozhong, Xu Yunjun. 2004. Tectonic evolution of the Nanhuabei area and analysis about petroleum potential, 28(4): 450-463 
[99] Xu Liming, Zhou Lifa, Zhang Yikai, Dang Ben. 2006. Characteristics and tectonic setting of Tectono-Stress field of Ordos Basin. Geotectonica et Metallogenia, 30(4): 455-462

[100] Xu Yigang, Li Hongyan, Pang Chongjin, He Bin. 2009. On the timing and duration of the destruction of the North China craton. Chinese Science Bulletin, 54(14): 19741989

[101] Xu Yigang. 2006. Formation of the Taihangshan Gravity lineament by the Diachronous lithospheric thinning of the North China craton. Earth Science-Jburnal of China University of Geosciences, 31(1): 14-22

[102] Xu Zhengyu, Lin Ge, Liu Chiyang, Wang Yuejun, Guo Feng. 2004. A discussion on amalgamation course between the South China and North China blocks: evidences from deformational characters in the Jianghan Superimposed Basin. Chinese Journal of Geology, 39(2): 284-295

[103] Xu Wenliang, Wang Dongyan, Wang Simin. 2000. p-T-t-c model of Mesozoic and Cenozoic volcanisms and lithospheric evolution in Eastern China. Journal of Changchun University of Science and Techonology, 30(4): 329-335

[104] Xu Shihong, Zhong Jianhua, Liu Zhongliang. 2007. Activity characteristics and controlling factors of the faults in the Hefei basin. Geotectonica et Metallogenia, 31(1): 31-36

[105] Yan Yi, Lin Ge, Li Zi'a, He Shijie, Xu Zhengyu. 2003. Detrital composition of Mesozoic sandstone and its implication for provenance and tectonic evolution of Beipiao (JinYang) Basin, Western Liaoning Province. Acta Sedimentologica Sinica, 21(3): 441447

[106] Yan Kongde. 1989. Tectonic conditions for formation of hypabyssal coal-generated gas deposits in Huainan-Huaibei Coalfield of Anhui. Journal of Anhui University of Science and Technology (Natural Science), 3: 1-8

[107] Yang Baojun, Zhang Mingsheng, Wang Pujun. 2003. Geological and geophysical analysis of the oil and gas region in China. Beijing: Science Press, 34-105

[108] Yang Geng, Chai Yucheng, Wu Zhengwen. 2001. Thin-skinned thrust nappe structures in Western Liaoning in the eastern sector of the Yanshan orogenic belt. Acta Geologica Sinica, 73(3): 322-332

[109] Yang Jinhui, Wu Fuyuan. 2009. Triassic magmatism and its relation to decratonization in the eastern North China Craton. Science in China, Ser.D, 39(7): 910-921

[110] Yang Minghui, Liu Chiyang, Zheng Menglin, Lan Chaoli, Tang Xuan. 2007. The two different types of marginal sequence architecture and their responses to the Middle-Late Triassic tectonic movement in Ordos basin. Science in China, Ser.D, 37(A01): 173-184

[111] Yang Minghui, Wang Simin, Chen Shanyong, Ming Haihui, Tang Xuan. 2005. Genetic classification and distribution of Ordovician carbonate buried-hills in Huanghua depression Bohai Bay basin. Oil \& Gas Geology, 26(3): 310-316

[112] Yang Minghui, Wang Simin, Zheng Xiaofeng, Wang Jinxiu, Bai Hua, Zeng Peng. 2009. Aeromagnetic anomalies characteristics and tectonic subareas of Southern North China craton and adjacent regions. Geological Review, 55(6): 862-872

[113] Yang Minghui, Liu Chiyang, Sun Dongsheng, Cui Yongqian. 2002. Extensional tectonic system and its deep-seated setting of Jizhong basin, China. Geotectonica et Metallogenia, 26(2): 113-120 
[114] Yang Minghui, Zhou Xinhuai, Wei Gang, Liu Le, Li Chunxia, Zheng Xiaofeng, Liu Xiaojian, Gao Libao. 2008. Segment, Linkage, and Extensional Fault-Related Fold in Western Liaodong Bay Subbasin, Northeastern Bohai Sea, China. Journal of China University of Geosciences, 19(6): 602-610

[115] Yang Nong, Chen Zhengle, Lei Weizhi, Zhang Huixu. 1996. Research on characteristics of Indosinian in Yanshan area of Norhtern Hebei. Beijing: Geology Press, 90

[116] Yang Shirong. 1994. Late Triassic-Jurassic sporopollen assemblages from Yima Area, Henan. Acta Palaeontologica Sinica, 33(6): 765-779

[117] Yin Hongfu, Du Yuansheng, Xu Jifeng, Sheng Jihu, Feng Qinglai. 1996. Radiolarian Fauna firstly discovered in Mian-Lüe paleo-suture belt of South Qinling Mountains. Earth Science-Journal of China University of Geosciences, 21: 184

[118] Yu Fusheng, Qi Jiafu, Wang Chunying. 2002. Tectonic deformation of Indosinian Period in eastern part of North China. Journal of China University of Mining \& Technology, 31(4): 402-406

[119] Yu Hezhong, Han Shouhua, Xie Jinlong, Guo Qingxin, Wu Jinyun. 2006. Types of original sedimentary basins and tectonic evolution on southeastern margin of North China plate. Oil \& Gas Geology, 27(2): 244-252

[120] Zhai Mingguo, Zhu Rixiang, Liu Jianming, Meng Qingren, Li Zhong, Zhang Hongfu, Hou Quanlin, Hu Shengbiao, Liu WEi. 2003. The vital transition period of Mesozoic tectonic regime in the eastern part of North China. Science in China, Ser.D, 33(10): 913-920

[121] Zhang Guoren. 2006. Mesozonic interplate orogenesis in Western Liaoning Province. A doctoral dissertation submitted to China University of Geosciences, 1-119

[122] Zhang Guowei, Dong Yunpeng, Lai Shaocong. 2003. The Mian-lue structural belt and suture zone in the south edge of Qinling-Dabie orogenic belt. Science in China, Ser.D, 33(12): 1121-1135

[123] Zhang Guowei, Dong Yunpeng, Yao Anping. 2001. Review on the development of studies on the tectonic and orogen process of orogenic belt, and discussing on some new key problems. Northwestern Geology, 34(1): 1-9

[124] Zhang Guowei, Meng Qingren, Lai Shaocong. 1995. Tectonics and structure of Qinling orogenic belt. Science in China (Series B), 25(9): 994-1003

[125] Zhang Hong. 1996. Mesozoic and Cenozoic Palaeotectono-stress field of Ordos basin. Journal Geology \& Mineral Resources North China, 11(1): 87-92

[126] Zhang Hongbo. 2006. Stratigraphy and sedimentary facies study of Mesozoic in Dongpu and surrounding regions. A doctoral dissertation submitted to China University of Geosciences, 1-119

[127] Zhang Jinfang. 2002. Filling and evolving of Mesozonic basin in Chengde District and its relationship with tectonics. A doctoral dissertation submitted to China University of Geosciences, 1-63

[128] Zhang Yong. 2006. Mesozoic thrust tectonics around Cenozoic Yanqing-Huailai basin and their geological implications, Northwest of Beijing Municipality. A masteral dissertation submitted to China University of Geosciences, 1-74

[129] Editorial Committee of Petroleum Geology of the Changqing Oil Field. 1992. Petroleum Geology of China (Vol.12): the Changqing Oil Field. Beijing: Petroleum Industry Press 
[130] Zhao Hongge, Liu Chiyang, Wang Jianqiang, Wang Feng, Yin Yan. 2007. Tectonic attribute of the western Ordos basin during the Late Triassic. Geology in China, 34(3): 384-391

[131] Zhao Wenzhi, Wang Xinmin, Guo Yanru, Liu Huaqing, Bai Yunlai. 2006. Restoration and tectonic reworking of the Late Triassic basin in western Ordos Basin. Petroleum Expoloration and Development, 33(1): 6-13

[132] Zhao Yue. 1990. The Mesozoic orogenies and tectonic evolution of the Yangshan Area. Geological Review, 36(l): 1-13

[133] Zhao Chongyuan, Liu Chiyang. 1990. The regional tectonics of Mesozoic-Cenozoic in North China craton and the formation and evolution of petroliferous basin. In: Zhao C Y, Liu C Y, et al. The formation and evolution of the sedimentary basins in North China craton and its hydrocarbon occurrence. Northwest University Press, 10-21

[134] Zhao Chongyuan, Liu Chiyang. 1992. The remnant intracraton basin and its oil-bearing properties,Ordos Basin and Sichuan basin. In: Geological Society of China. Collection on thesis of "75" Academic Exchanges Conference about the important achievement of geological techology. Beijing: Science \& Techology Press, 610-613

[135] Zhao Zongju, Yang Shufeng, Chen Hanlin, Zhu Guoqiang, Zhou Jingao. 2000. Tectonic attribute of basement in Hefei basin, Anhui Province, China. Scientia Geologica Sinica, 35(3): 288-296

[136] Zhao Zongju, Li Dacheng, Zhu Yan, Zhou Jingao, Feng Jialiang. 2001. The structure evolution and the petroleum system in Hefei basin. Petroleum Exploration and Development, 28(4): 8-13

[137] Zheng Qiugen, Zhang Yumin, Zhao Deyong, Liu Zhiqin. 1998. Tectonic evolution and Upper Triassic distribution in the Western Henan. Henan Petroleum, (2): 5-10

[138] Zheng Yadong, Davis G A, Wang Cong, Darby B J, Zhang Wenhou. 2000. The main questions of tectonic events and plate tectonics in Yanshan Belt. Acta Geologica Sinica, 74(4): 289-302

[139] Zheng Yadong, Wang Shizheng, Wang Yufang. 1990. The newly discovered oversize nappe structures and extentional metamorphic core complexes in the margin area between China and Mongolia. Science in China, Ser.B, (12): 1299-1305

[140] Zheng Yadong, Wang Tao. 2005. The kinematic and dynamic analysis of the Mesozoic nappe structures and extensional sloughing regime in the margin area between China and Mongolia. Science in China, Ser.D, 35(4): 291-303

[141] Editorial Committee of Petroleum Geology of the Central Plains Oil Field. 1993. Petroleum Geology of China (Vol.7): the Central Plains Oil Field. Beijing: Petroleum Industry Press, 250-256

[142] Zhou Xinke, Xu Huazheng, Hu Zongquan, Wang Chuangang. 2005. Characteristics of prototype basin and hydrocarbon potential evaluation of the Late Triassic in the west Henan Province. Petroleum Geology \& Expeximent, 27(3): 211-217

[143] Zhou Jing'ao, Zhao Zongju, Deng Hongying. 1999. Tectonic evolution of the Hefei Basin and analysis of its petroleum potential. Acta Geologica Sinica, 73(1): 15-23

[144] Zhu Yanming, Qin Yong, Fan Bingheng, Li Tianzhong, Jiang Bo. 2001. Restoration and significance of the original thickness of Triassic system in Baohaiwan Bay basin. Journal of China University of Mining \& Technology, 30(2): 195-200 
[145] Zong Guohong, Shi Yangsheng, Wang Binghai, Wang Jie. 1998. Mesozoic structures and their relations to hydrocarbon traps in the Jiyang basin. Geological Review, 44(3): 289-294 


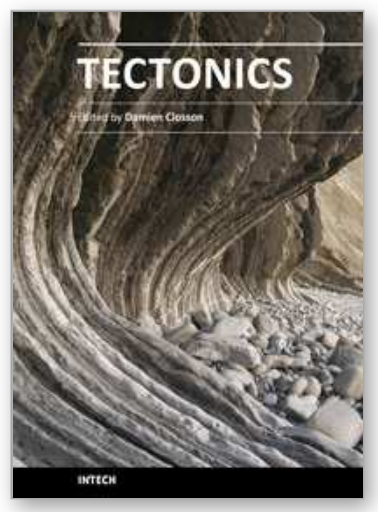

\author{
Tectonics \\ Edited by Dr. Damien Closson
}

ISBN 978-953-307-545-7

Hard cover, 358 pages

Publisher InTech

Published online 28, February, 2011

Published in print edition February, 2011

The term tectonics refers to the study dealing with the forces and displacements that have operated to create structures within the lithosphere. The deformations affecting the Earth's crust are result of the release and the redistribution of energy from Earth's core. The concept of plate tectonics is the chief working principle.

Tectonics has application to lunar and planetary studies, whether or not those bodies have active tectonic plate systems. Petroleum and mineral prospecting uses this branch of knowledge as guide. The present book is restricted to the structure and evolution of the terrestrial lithosphere with dominant emphasis on the continents. Thirteen original scientific contributions highlight most recent developments in seven relevant domains: Gondwana history, the tectonics of Europe and the Near East; the tectonics of Siberia; the tectonics of China and its neighbourhood; advanced concepts on plate tectonics are discussed in two articles; in the frame of neotectonics, two investigation techniques are examined; finally, the relation between tectonics and petroleum researches is illustrated in one chapter.

\title{
How to reference
}

In order to correctly reference this scholarly work, feel free to copy and paste the following:

Yang Minghui, Liu Chiyang, Zeng Peng, Bai Hua and Zhou Jin (2011). Proto-Basin Types of North China Craton (NCC) in Late Triassic and Its Implication for Regional Tectonics of Initial Craton Destruction, Tectonics, Dr. Damien Closson (Ed.), ISBN: 978-953-307-545-7, InTech, Available from: http://www.intechopen.com/books/tectonics/proto-basin-types-of-north-china-craton-ncc-in-late-triassic-and-itsimplication-for-regional-tecton

\section{INTECH}

open science | open minds

\section{InTech Europe}

University Campus STeP Ri

Slavka Krautzeka 83/A

51000 Rijeka, Croatia

Phone: +385 (51) 770447

Fax: +385 (51) 686166

www.intechopen.com

\section{InTech China}

Unit 405, Office Block, Hotel Equatorial Shanghai

No.65, Yan An Road (West), Shanghai, 200040, China 中国上海市延安西路65号上海国际贵都大饭店办公楼 405 单元

Phone: +86-21-62489820

Fax: +86-21-62489821 
(C) 2011 The Author(s). Licensee IntechOpen. This chapter is distributed under the terms of the Creative Commons Attribution-NonCommercialShareAlike-3.0 License, which permits use, distribution and reproduction for non-commercial purposes, provided the original is properly cited and derivative works building on this content are distributed under the same license. 